\title{
Y32 Bojisinin Yapısal Analizleri, Bölüm 1: Statik Analizler
}

\author{
Oğuzhan Konez ${ }^{1}$, Muzaffer Metin ${ }^{2 *}$, Özgür Demir ${ }^{3}$ \\ ${ }^{1}$ Yıldız Teknik Üniversitesi, Makine Fakültesi, Makine Mühendisliği Bölümü, İstanbul, Türkiye \\ 2 Yıldız Teknik Üniversitesi, Makine Fakültesi, Makine Mühendisliği Bölümü, İstanbul, Türkiye (ORCID: 0000-0002-9724-3433) \\ ${ }^{3}$ Yıldız Teknik Üniversitesi, Gemi İnşaatı ve Denizcilik Fakültesi, Gemi İnşaatı ve Gemi Makineleri Mühendisliği Bölümü, İstanbul, Türkiye (ORCID: 0000-0003- \\ 0865-0684)
}

(İlk Geliş Tarihi 9 Ağustos 2019 ve Kabul Tarihi 27 Ekim 2019)

(DOI: 10.31590/ejosat.604855)

ATIF/REFERENCE: Konez, O., Metin, M \& Demir, Ö. (2019). Y32 Bojisinin Yapısal Analizleri, Bölüm 1: Statik Analizler. Avrupa Bilim ve Teknoloji Dergisi, (17), 366-387.

\section{$\ddot{O} \mathbf{z}$}

Bojiler, demiryollarında kullanılan araçları taşımaya yarayan mekanik sistemlerdir. Tekerlek setleri, aks kutusu, fren donanımı, bolster, yatay damper, birincil ve ikincil süspansiyonlar boji şasisi üzerinde yer alır. Düz hatve kurplarda aracın dengeli şekilde ilerlemesini sağlamak, araç hızla ilerlerken raydaki düzensizliklerden kaynaklanan titreşimleri absorbe etmek ve raylardaki aşınmayı minimize etmek bojinin görevleri arasındadır. Raylı taşıtlarda kullanılan en kritik elemanlardan birisi olan boji şasisinin son derece güvenli tasarlanması ve imal edilmesi önemli bir gerekliliktir. Bunun için raylı sistemlerde güvenlik açısından katı kuralları içeren standartlar kullanılmaktadır. TS EN 13749 standardı Türkiye tarafindan kabul edilen ve uygulanan bir standarttır. Bu standart boji şasilerinin yapısal gerekliliklerini belirler. İki bölümden oluşan bu çalışmanın birinci bölümünde; Y32 boji şasisinin aşırı yük durumlarındaki statik analizleri sonlu elemanlar yöntemi kullanılarak (SEY) gerçekleştirilmiş ve TS EN 13749 standardınca uygunluğu değerlendirilmiştir. Analizleri gerçekleştirmek için öncelikle Y32 Bojisinin üç boyutlu (3B) katı modeli oluşturulmuştur. 3B katı modelleme işlemi Solidworks yazılımı kullanılarak gerçekleştirilmiştir. Yapısal analizler için ise sonlu elemanlar yöntemi tabanlı Ansys Workbench yazılımı kullanılmıştır. Oluşturulan 3B katı model sonlu elemanlara hazırlık aşaması ve çözüm ağı oluşturulması amacıyla Ansys Workbench yazılımına aktarılarak, gerekli görülen geometrik düzenlemeler ve çözüm ağına ayırma işlemi gerçekleştirilmiştir. Modelleme işleminde herhangi bir basitleştirmeye gidilmemiş olup, gerçekçi bir model kurulmuştur. Modelde uygun şekilde çözüm ağı oluşturulmuş, TS EN 13749 standardı dikkate alınarak sınır şartları ve kuvvetler uygulanmıştır. Yapısal analizlerde kullanılan malzemelerin mekanik özellikleri tanımlanmış ve parçalar arası bağlantılar Ansys Workbench yazılımı içerisinde kurulmuştur. Yapısal analizler neticesinde elde edilen sonuçlar TS EN 13749 standardında izin verilen malzeme limit değerleri dikkate alınarak değerlendirilmiş uygun olmayan koşullar için çözüm önerileri sunulmuştur. Çalışmanın ikinci bölümünde ise, normal servis yüklemesi koşulu altında Y32 bojisinin yorulma analizleri gerçekleştirilmiş olup, her düğüm noktasına karşılık gelen ortalama gerilme ve gerilme genliği değerleri hesaplanmış ve yorulma sonuçları Haigh ve Goodman Diyagramları'nda ayrı ayrı değerlendirilmiştir.

\section{Structural Analysis of Y32 Bogie Under Exceptional Conditions Part 1: Static Analysis}

\begin{abstract}
* Sorumlu Yazar: Yıldız Teknik Üniversitesi, Makine Fakültesi, Makine Mühendisliği Bölümü, İstanbul, Türkiye, ORCID: 0000-0002-9724-3433, mmetin@yildiz.edu.tr
\end{abstract}


Bogies are mechanical systems which carry vehicles in railway systems. Wheelsets, axle boxes, brake equipment, bolster, horizontal damper, primary and secondary suspensions are assembled to the bogie frame. Balancing the vehicle on straight rails and curves, absorbing the vibrations caused by irregularities on the track, causing minimum wear and irregularity on the rails are also among the tasks of the bogie. It is an important requirement that the bogie frame, which is one of the most critical elements used in rail vehicles, is designed and manufactured safely. For this purpose, safety standards which have strict rules are used in rail systems. EN 13749 is a standard which is accepted and implemented by Turkey. This standard determines the structural conditions of the bogie frame. The aim of the first part of this two-series study is to investigate the conformity with the EN 13749 standard by performing the finite element method under exceptional loads and to offer solutions for unfavorable conditions.

3D solid modeling has been performed using Solidworks software. Ansys Workbench has been used for structural analyses. The 3D solid model was transferred to Ansys Workbench software for the preparation of finite elements and the necessary geometric arrangements have been performed. No simplification method has made in the modeling process and a realistic model has been established. In the model, a suitable finite element mesh has been established and boundary conditions and forces have been applied in accordance with TS EN 13749 standard. The mechanical properties of the materials used in the structural analysis have been defined and the connections have been done in Ansys Workbench environment. The results obtained from the structural analyses have been evaluated considering the material limit values allowed in TS EN 13749 standard and suggestions have been proposed for non-suitable conditions. In the second part of this study, fatigue analysis of Y32 bogie has been performed under normal service loading condition. In fatigue analysis, mean stress and alternating stress results of each node have been deduced and these results have been evaluated on the High Diagram and also Goodman Diagram too.

Keywords: Y32 Bogie, Static Analysis, Finite Element Method, Exceptional Load

\section{Giriş}

Y32 Bojisi Tüvasaş tarafindan üretilir ve yine Tüvasaş tarafından üretilen TVS 2000 serisi vagonlarda kullanılırlar. Boji şasisi çelik plakaların birbirlerine kaynatılmasıyla üretilir. Birincil ve ikincil süspansiyon sistemine sahip olan Y32 bojisi bir adet yanal dampere sahiptir. Bolsterlı boji sınıfına giren Y32 bojisinin vagon sandığı ile bağlantısı cer halatı sayesinde olmaktadır. Y32 bojisi 4 adet fren diskine sahiptir. Aks yükü 16 tondur. Maksimum servis hız1 $160 \mathrm{~km} / \mathrm{sa}$ olan Y32 bojisinin Sperling metoduna göre $140 \mathrm{~km} / \mathrm{sa}$ 'te sürüş kalitesi $2.5^{\prime}$ tir (Wz). Y32 Bojileri tip onay analiz ve testleri yapılırken aşırı yükleme koşulları dikkate alınmaz, normal yükleme koşullarında çalıştı̆ı varsayılır. Ancak, raylı sistem araçları aşırı yükleme koşullarına da maruz kalabilmektedir. Bu nedenle, bu çalışmada genel uygulamalardan ve literatürde yer alan araştırmalardan farklı olarak aşırı yükleme koşullarında bojinin yapısal davranışı incelenmiş ve elde edilen sonuçlar yorumlanmıştır.

Raylı sistemler dünyada yaygın olarak kullanıldıkları için pek çok farklı ülkeden çeşitli akademik araştırmalar gerçekleştirilerek literatüre kazandırılmıştır. Ancak bojiler üzerine nitelikli araştırmaların sayısı oldukça sınırlıdır. Aşağıda boji üzerinde uygulanan analiz çalışmalarından bazıları anlatılmıştır.

Sabırlı İstanbul'da kullanılacak olan bir tramvay bojisinin yorulma analizini gerçekleştirmiştir. Yorulma analizini TS EN 13749 standardına göre gerçekleştirmiş ve analiz sonuçlarını Haigh Diyagramı'nda değerlendirmiştir [1]. Zhang yüksek hızlı EMU trenlerinin motor bojileri için aşırı yük durumları, normal servis yüklemesi durumları ve modal analizi ile ilgili bir makale yazmıştır. Çalışmasını UIC 615-4 standardına göre yapmıştır [2]. Hindistan'da LHB (Linke Hofmann Busch) yolcu vagonları FIAT boji şasisi kullanmaktadır. $\mathrm{Bu}$ bojinin limitlerini iyileştirmek amacıyla yeni CASNUB boji şasisinin LHB yolcu vagonları için kullanılıp kullanılamayacağı Bhadraiah tarafından araştırılmıştır. Analiz programı olarak Ansys Mechanical APDL kullanılmıştır [3]. Haldar ve Verma, döküm metodu ile üretilen bir boji ile plakaları kaynatılarak üretilen bir bojinin yük durumları karşısında gösterdikleri farkları araştırmışlardır. Analizde Ansys Workbench programı kullanılmıştır. Analiz sonuçları, üretim metodları arasındaki farklılıklar ve güvenirlilik gibi pek çok faktör göz önüne alındığında plakaları kaynatılarak üretilen boji daha avantajlı olarak görülmüştür [4]. Tang, bir DMU (Diesel Multiple Units) trenlerinin bojilerinin yorulma ve modal analizlerini gerçekleştirmiştir. Çalışmada Ansys programı kullanılmış olup analizler UIC standardına göre yapılmıştır [5]. Dizo, Harusinec ve Blatnicky modifiye edilmiş bir yük vagonu bojisinin yapısal analizlerini gerçekleştirmişlerdir. EN 13749 standardına göre yapılan analizde Ansys programı kullanılmış olup sonuçlar paylaşılmıştır [6]. Cera, boji şasisinin yorulma analizleirni yapmışlardır. Analizler EN 13749 standardına göre yapılmış ve Ansys programı kullanılmıştır. Analizde kaynaklı bölgelere ayrıca önem gösterilmiştir. Farklı metodlarda yorulma analizleri uygulanmış ve hangisinin daha doğru sonuçlar verdiği araştırılmışıı [7]. Dai, yüksek hızlı bir trenin boji şasisinin mukavemet analizi ile ilgili bir makale yazmıştır. Analizleri Ansys programında gerçekleştirmiştir. Kullandığı standard ise "Bullet Train Bogie Frame Strength Test Method" (TB/T23682005) olarak geçmektedir. Bulduğu deplasman ve gerilme sonuçları referans aldığı standarda göre uygun değerlerdedir [8].

Kim ve Kim bir yalpalı tren bojisinin yorulma analizini gerçekleştirmiştir. Yalpalı trenler kurplara girdikleri zaman daha hızlı hareket edecek şekilde tasarlanmışlardır. Yorulma analizinde Goodman Diyagramı kullanılmıştır. Yorulma analizindeki sonuçların diyagrama bakılarak uygun olduğu belirtilmiştir [9]. Huang ve Chen bir bojinin EN 13749 standardına göre yorulma analizini gerçekleştirmişlerdir. Buna ek olarak tren hızının bojinin yorulmadaki çevrim süresini nasıl etkilediğini araştırmışlardır. Trenin hızı arttıkça bojinin yük çevrim ömrü de ciddi oranda azalmaktadır [10].

Bu çalışmanın burada yer alan birinci bölümünün amacı ise, Y32 boji şasisinin aşırı yük durumlarında (statik analiz) TS EN 13749 standardına uygun olarak yapısal analizinin gerçekleştirilmesidir [11]. Bunun için, boji şasisinin üç boyutlu katı modeli çıkarılmış ve Ansys Workbench programında çözüm ağı (mesh) oluşturulmuştur. Analizler için boji geometrisinde herhangi bir basitleştirmeye 
gidilmemiştir. Boji şasisinde kullanılan malzememin mekanik özellikleri belirlenmiştir. Standarda uygun şekilde sınır şartları ve kuvvetler uygulanmıştır. Aşırı yük durumlarında analiz sonuçlarındaki deformasyon ve gerilme değerleri incelenmiştir. Statik analizler sonucunda malzemelerin akma gerilmesine (yielding) maruz kalıp kalmadığına bakılmıştır.

\section{Y32 Bojisi}

Y32 Bojisi şehirlerarası demiryollarında kullanılmak üzere tasarlanmıştır. 1970 yılında tasarlanan boji 1975 y1lında De Dietrich firması tarafından üretilmeye başlanmıştır. Bu Fransız şirketini 1990'lı yıllarda Alstom firması kendi bünyesine katmıştır. Tüvasaş, 10 Şubat 1989 tarihinde De Dietrich firması ile bir lisans anlaşması yapmış ve Y32 Bojilerini üretmeye başlamıştır. Y32 Bojisi günümüzde Hollanda, Portekiz, Fas, İspanya ve Türkiye'de kullanılmaktadır [12].

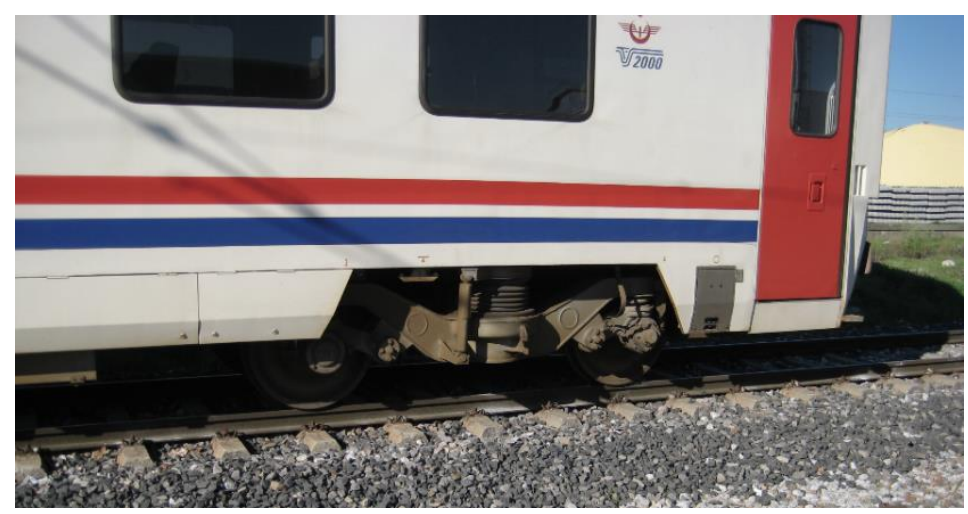

Şekil 1. TVS 2000 Serisi vagonlarını taşıyan Y32 Bojisi [12]

Y32 bojisinin araç üzerindeki görünüşü ve izometrik üç boyutlu katı modelleri Şekil 1 ve Şekil 2'de görülmektedir. Boji toplam kütlesi $5750 \mathrm{~kg}$ olup şasi ağırlığı 2200 kg'dır. Bu çalışmada yalnızca boji şasisi, dingil-şasi irtibat kolları ve akslar incelenmiştir.
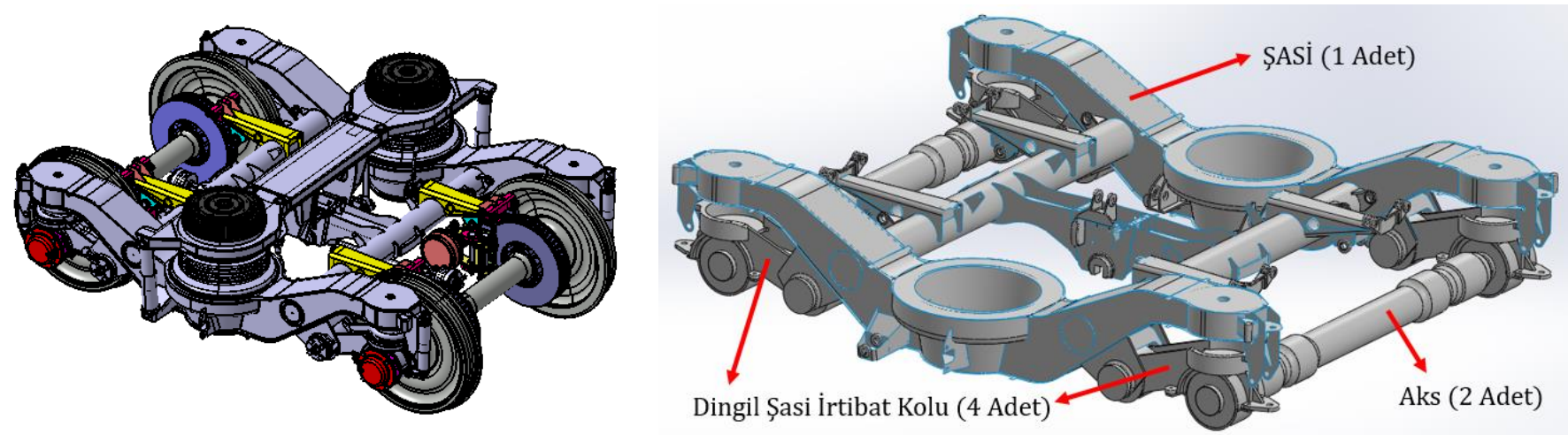

Şekil 2. Y32 Bojisinin ve şasisinin izometrik görünüşleri

Y32 bojisinin üzerindeki lastik dayama, boji çekme mekanizması, yanal stop plakası ve bu parçaların görünüşü Şekil 3'te verilmiştir. 


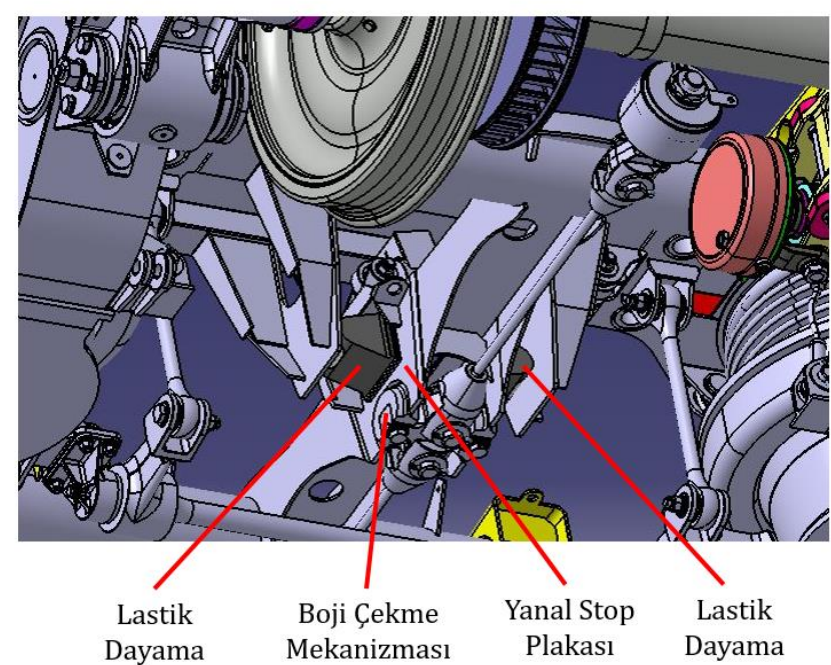

Şekil 3. Y32 bojisinin üzerinde bulunan parçalar

\subsection{Boji Malzemeleri}

Şaside kullanılan çelik malzemenin Alman standardına göre kalitesi St52-3N'dir. Avrupa standardına göre ise bu çelik kalitesi EN 10025-2 S355J2G3 olarak geçmektedir. St52-3N çeliği yapısal çelik sınıfına girer, alaşımsız bir çelik çeşididir. Dingil şasi irtibat kolunda kullanılan malzeme Alman standardına göre GS 45-3 kalitesinde çelik dökümdür. Bu çelik döküm türü Avrupa standardına göre GE 240 olarak geçmektedir. Makine elemanlarında genel olarak kullanılan bir çelik kalitesidir [14]. Akslarda kullanılan çelik kalitesi EA1N'dir ve özel bir çelik kalitesidir. Akslar üretilirken sıcak dövme, talaşlı imalat, ısıl işlem ve taşlama işlemlerinden geçer. Tablo 1'de bu malzemelere ait mekanik özellikler verilmiştir.

Tablo 1. Y32 Bojisi için malzeme özellikleri [13]-[15]

\begin{tabular}{l|l|l|l}
\hline \multirow{2}{*}{ Malzeme Özelliği } & Boji Şasisi (St52-3N) & $\begin{array}{l}\text { Dingil-Şasi İrtibat Kolu } \\
\text { (GS45-3) }\end{array}$ & Aks (EA1N) \\
\cline { 2 - 4 } & Değeri & Değeri & Değeri \\
\hline Young Modülü & $190.000 \mathrm{MPa}$ & $200.000 \mathrm{MPa}$ & $200.000 \mathrm{MPa}$ \\
\hline Poisson Oranı & 0,29 & 0,30 & 0,30 \\
\hline Çekmedeki Akma Dayanımı & $325 \mathrm{MPa}$ & $260 \mathrm{MPa}$ & $320 \mathrm{MPa}$ \\
\hline Basmadaki Akma Dayanımı & $325 \mathrm{MPa}$ & $260 \mathrm{MPa}$ & $320 \mathrm{MPa}$ \\
\hline Kopma Dayanımı & $510 \mathrm{Mpa}$ & $450 \mathrm{Mpa}$ & $550 \mathrm{Mpa}$ \\
\hline $\begin{array}{l}\text { Yorulma Dayanımı } \\
\left(10^{6} \text { Çevrim İçin) }\right.\end{array}$ & $210 \mathrm{MPa}$ & $200 \mathrm{MPa}$ & $200 \mathrm{MPa}$ \\
\hline
\end{tabular}

\section{Analiz Modelinin Hazırlanması}

\subsection{Y32 Boji Modeli}

Sac metal yapısal özelliğine sahip boji şasisi üzerinde orta yüzey (mid-plane) olarak modellenen kısımlara ek olarak solid modelleme yapılan parçalardan oluşturulmuştur. $\mathrm{Bu}$ amaçla boji şasinin orta yüzeyi çıkarılacak parçalara gerekli CAD işlemi uygulanmıştır. Yüzey olarak modellenen boji şasisi parçaları üç düğüm noktalı (tria) eleman tipi kullanılarak ve katı olarak modellenen kısımlar için ise tet elemanlar yardımıyla sonlu eleman modellemesi gerçekleştirilmiş̧ir. Sonlu elemanlara ayırma işlemi sırasında ortalam eleman boyutu $20 \mathrm{~mm}$ olarak belirlenmiş olup, gerekli görülen bölge ve parçalarda $10 \mathrm{~mm}$ ile $30 \mathrm{~mm}$ arasında eleman boyutu kullanılmıştır.

Sonlu elemanlar yöntemi tabanlı Ansys Workbench yazılımı ile gerçekleştirilecek olan yapısal analizler için oluşturulan çözüm ağındaki (mesh) toplam eleman sayısı 449,596'dır. Şekil 4'te görülen çözüm ağında toplam düğüm noktası (node) sayısı ise 624,785'tir. 

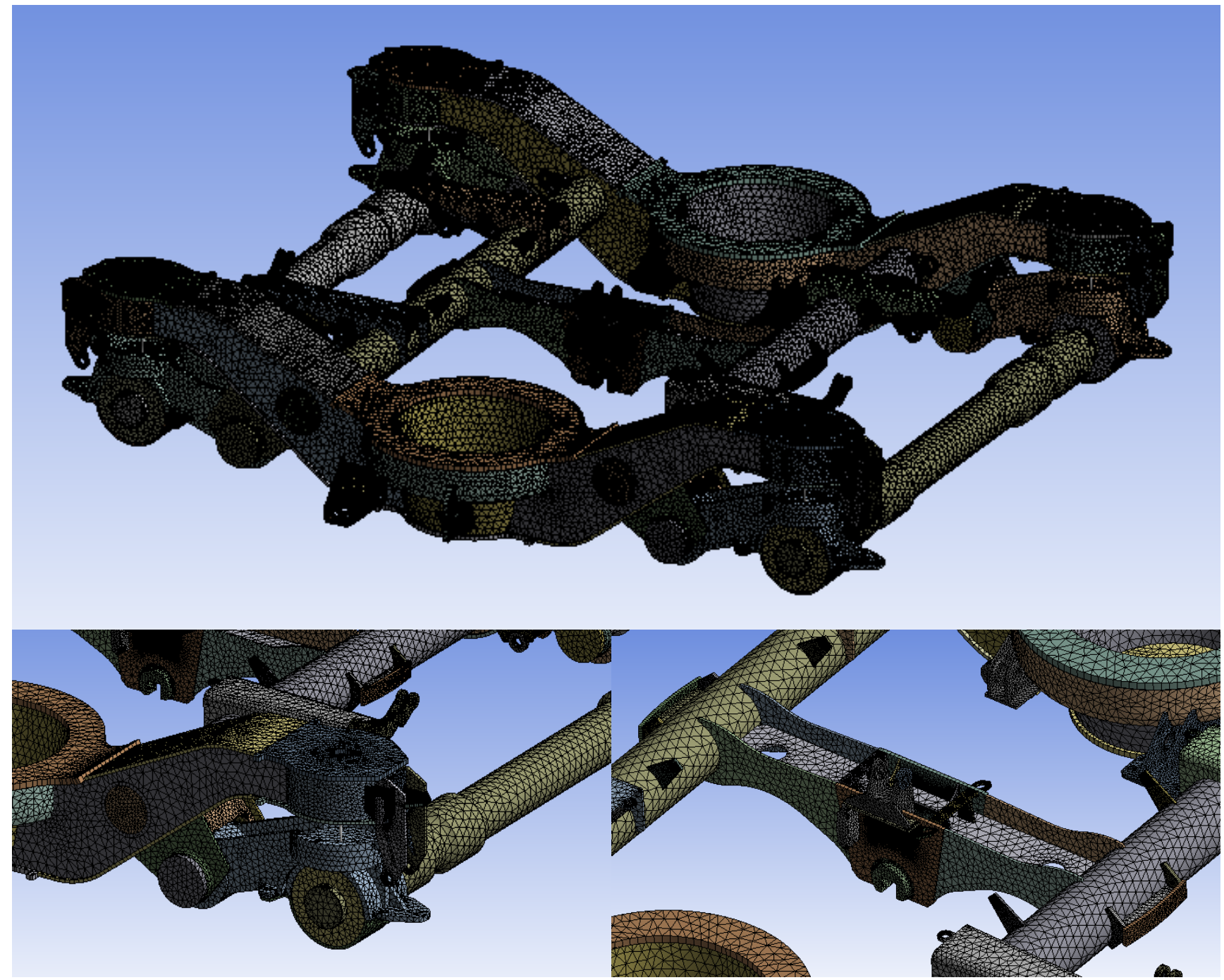

Şekil 4. Y32 Bojisi için oluşturulan çözüm ağı (mesh)

Çözüm ağındaki elemanların kalitesi "0" ile "1" arasında olan bir aralıkta belirlenir. Eğer bu sayı "1" ise eleman mükemmel kalitededir. "0"a doğru gittikçe elemanın kalitesi düşmektedir [16].

Sonlu Eleman 2 boyutlu ise (Üçgen veya dörtgen):

Eleman Kalitesi $=\mathrm{C}\left(\frac{\text { Alan }}{\sum(\text { Kenar Uzunluğu })^{2}}\right)$

Sonlu Eleman 3 boyutlu ise (Dört yüzlü veya Altı yüzlü):

Eleman Kalitesi $=\mathrm{C}\left(\frac{\text { Hacim }}{\sqrt{\left[\sum(\text { Kenar Uzunluğu })^{2}\right]^{3}}}\right)$

Tablo 2.Eleman şekline göre C değerleri [16]

\begin{tabular}{c|c}
\hline Eleman Şekli & C Değeri \\
\hline Üçgen & 6.9282 \\
\hline Dörtgen & 4.0 \\
\hline Dört yüzlü & 124.7076 \\
\hline Altı yüzlü & 41.5692 \\
\hline
\end{tabular}


Tablo 3.Çözüm ă̆ kalitesi istatistikleri

\begin{tabular}{c|c}
\hline $\begin{array}{c}\text { Düğüm Noktas1 } \\
\text { Sayıs1 }\end{array}$ & 624785 \\
\hline Eleman Sayıs1 & 449596 \\
\hline $\begin{array}{c}\text { Ortalama Eleman } \\
\text { Kalitesi }\end{array}$ & 0.7853 \\
\hline
\end{tabular}

Tablo 3'te gösterildiği gibi ortalama eleman kalitesi (üçgen + dört yüzlü) 0.79 'dur. Bu elemanların standart sapması ise 0.17 'dir. Maksimum eleman kalitesinin değeri 1'dir. Minimum eleman kalitesinin değeri ise 0.0065 'tir. Elemanların ortalama çarpıklık (skewness) değeri ise 0.3 'tür. 0.25 ile 0.5 arasındaki çarpıklık (skewness) değerleri "iyi" kategorisine girmektedir. Diklik kalitesi (ortogonal quality) incelendiğinde ortalama 0.81 çıkmaktadır. Bütün elamanlar arasındaki minimum diklik kalitesi 0.013 çıkmaktadır. Bu değer 0.01 'den büyük olmalıdır. Çözüm ağımızda ise bu değer 0.01 'den büyük çıkmıştır. Ansys yazılımı için geçerli çözüm ağı kalite özellikleri ve detayları programın kullanıcı dokümanlarında detaylı olarak bulunmaktadır ve analizler için bu değerler referans alınmıştır [16].

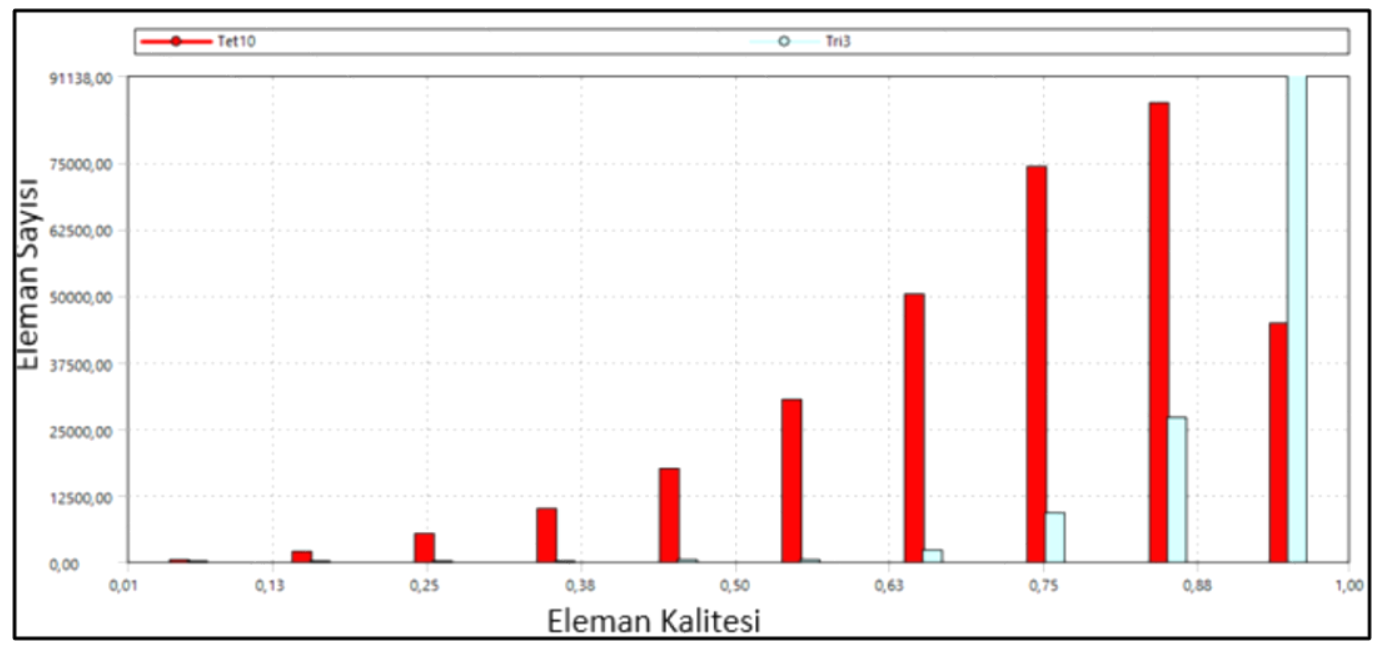

Şekil 5. Çözüm ă̆ındaki eleman kalite değerleri grafĭgi

Şekil 5’te açık (mavi) sütunlar yüzeylere (plakalara) uygulanan çözüm ağındaki üçgen şeklindeki elemanların kalite değerine göre adetleridir. Koyu (kırmızı) sütunlar ise katı modellerde bulunan dört yüzlü (tetrahedron) şeklindeki elemanların kalite değerlerine göre adetleridir.

Analizler için ANSYS 14.5 programı kullanılmıştır. Hesaplama için kullanılan bilgisayar $2.70 \mathrm{GHz}$ hızında 4 çekirdekli bir işlemciye ve 32 GB RAM'a sahiptir. Herbir analiz senaryosu için CPU çözüm süresi 180 ile $240 \mathrm{dk}$. arasında değişmektedir.

\subsection{Așırı Yük Durumlarında Kuvvetlerin Hesaplanması}

Aşırı yük durumlarında boji üzerine gelen kuvvetler TS EN 13749:2011 standardına uygun olarak hesaplanmıştır. Standart içinde yapılan boji sınıflandırmasında Y32 bojisi B-I kategorisine girdiğinden bu kategori altında belirtilen eşitlikler üzerinden hesaplamalar yapılmıştır [11].

Y32 bojisi taşıyıcı bojidir. Her yolcu vagonunun altında 2 adet boji bulunmaktadır. Bu nedenle bir vagonu 4 adet aks taşımaktadır. Y32 bojisinin aks yükü 16 ton olarak alınmıştır. Aşağıda, düşey, yanal ve boyuna gelen kuvvetlerin hesapları yer almaktadır. TS EN 13749 standardı dikkate alındığında, düşey kuvvetlerin araç, boji ve ekipmanların ağırlıkları neticesinde oluştuğu, yanal kuvvetlerin ise kurp geçişi sırasında teker-ray teması neticesinde oluştuğu kabul edilmektedir. Boyuna kuvvetler ise kurp geçişi sırasında aracın çekilmesi ve frenlemesi sırasında oluşan kuvvetlerdir.

\subsubsection{Düş̧ey Kuvvetler}

Tablo 4 'te kuvvet hesabında kullanılan parametreleri verilen ve Şekil 6’te düşey kuvvetleri gösterilen bojinin sağ ve sol olarak iki boylamsal yan kirişine de eşit kuvvetlerin geldiği ve araç gövdesinin bu kirişlerle direkt olarak taşındığı varsayılmıştır [11].

TS EN 13749 standardı kapsamında Denklem 3'te yük faktörü (load factor) 1.4 olarak alınmıştır. Bu değer özel durumlar için 2.0' a kadar büyütülebilmektedir. 
$\mathrm{F}_{\mathrm{z} 1 \max }=\mathrm{F}_{\mathrm{z} 2 \max }=\frac{\mathrm{F}_{\mathrm{zmax}}}{2}=\frac{1.4 \mathrm{~g}\left(\mathrm{M}_{\mathrm{V}}+\mathrm{P}_{1}-2 \mathrm{~m}^{+}\right)}{4}$

Tablo 4. Düssey Kuvvet Hesabinda Kullanılan Parametreler [17]

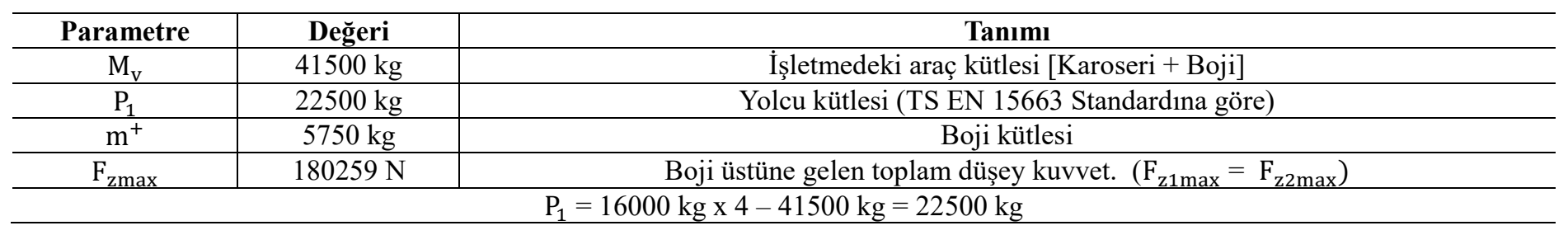

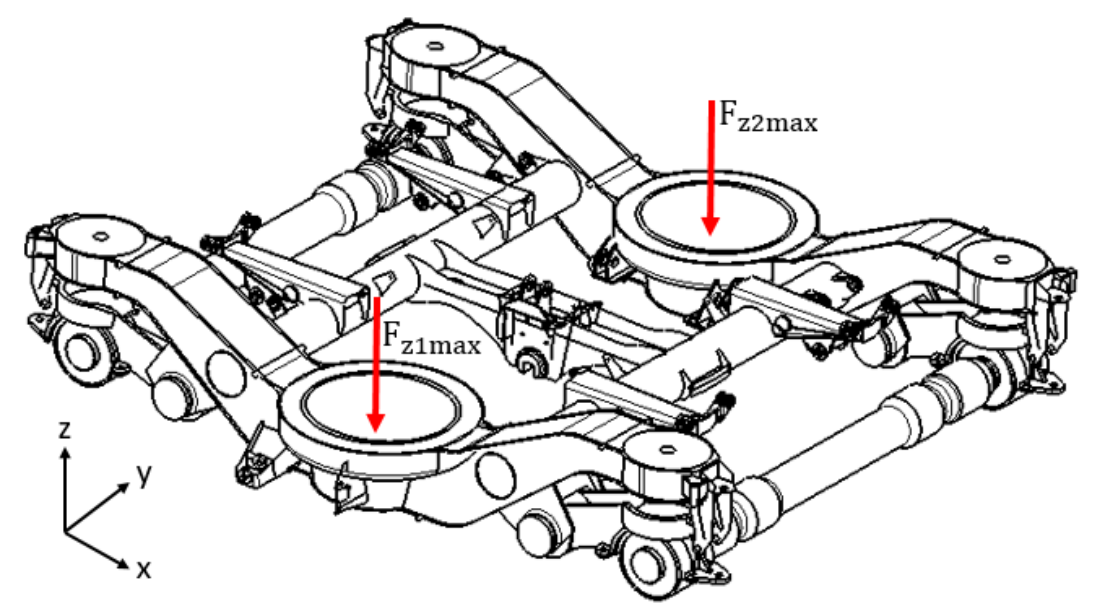

Şekil 6. Düşey kuvvetler

\subsubsection{Yanal Kuvvetler}

Şekil 7'da gösterilen yanal kuvvetler her iki aksa da eşit olarak uygulanır [11].

$\mathrm{F}_{\mathrm{y} 1 \max }=\mathrm{F}_{\mathrm{y} 2 \max }=\frac{\mathrm{F}_{\mathrm{ymax}}}{2}=10^{4}+\frac{\left(\mathrm{M}_{\mathrm{v}}+\mathrm{P}_{1}\right) \mathrm{g}}{12}$

burada, g yerçekimi ivmesidir, $9.81 \mathrm{~m} / \mathrm{s}^{2} . \mathrm{F}_{\mathrm{y} 1 \max }=\mathrm{F}_{\mathrm{y} 2 \max }=62320 \mathrm{~N}$

TS EN 13749 standardı dikkate alınarak hesaplanan yanal kuvvetler, kurp geçişi sırasında tekerlek-ray teması neticesinde oluşan kuvvetlerdir. Denklem 4'te enine kuvvetlerin hesabı ray üzerindeki yük tekrarı ve elde edilen deplasmanların kullanıldığı ampirik bir yaklaşım olan Prud'Homme sınırı göz önünde bulundurulmaktadır ve tüm demiryolu boji kategorileri için bu değer aynı kabul edilebilmektedir. Denklemde verilen $10^{4}$ değeri tekrarlanan deneyler sonucunda elde edilmiş ampirik bir değerdir.

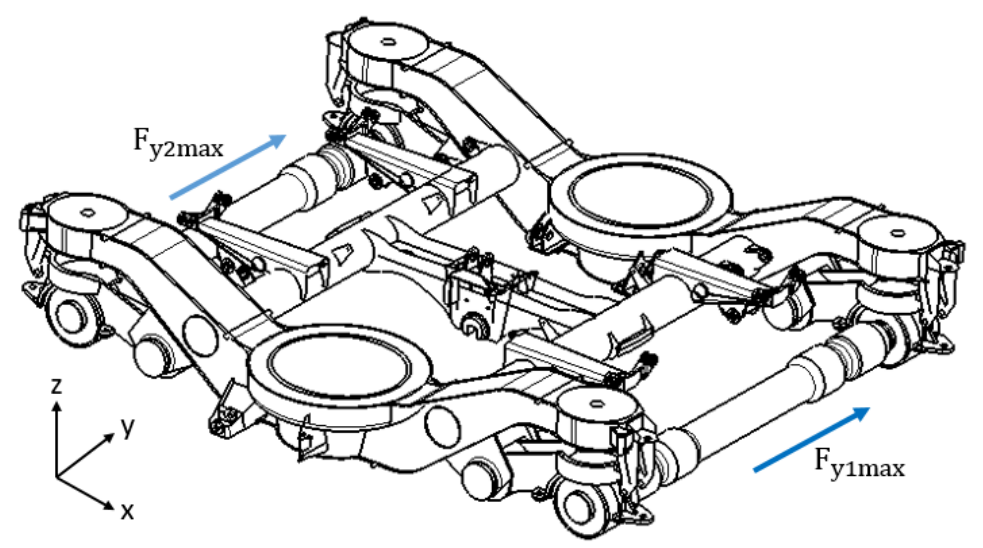

Şekil 7. Yanal kuvvetler 


\subsubsection{Boyuna Gelen Kuvvetler}

Bu kuvvetler tekerleklere (tekerleklerin bağlandığı aksa) uygulanır. Sağ yanal kirişe yakın olan tekerlere negatif yönde (x doğrultusunda) sol yanal kirişe yakın olan tekerlere pozitif yönde (x doğrultusunda) kuvvet uygulanır (Şekil 8) [11].

$$
\mathrm{F}_{\mathrm{x} 1 \mathrm{max}}=0.1 \mathrm{x}\left(\mathrm{F}_{\mathrm{zmax}}+\mathrm{m}^{+} \mathrm{g}\right)
$$

burada, $\mathrm{F}_{\mathrm{x} 1 \max }=41693 \mathrm{~N}$ olarak bulunur.

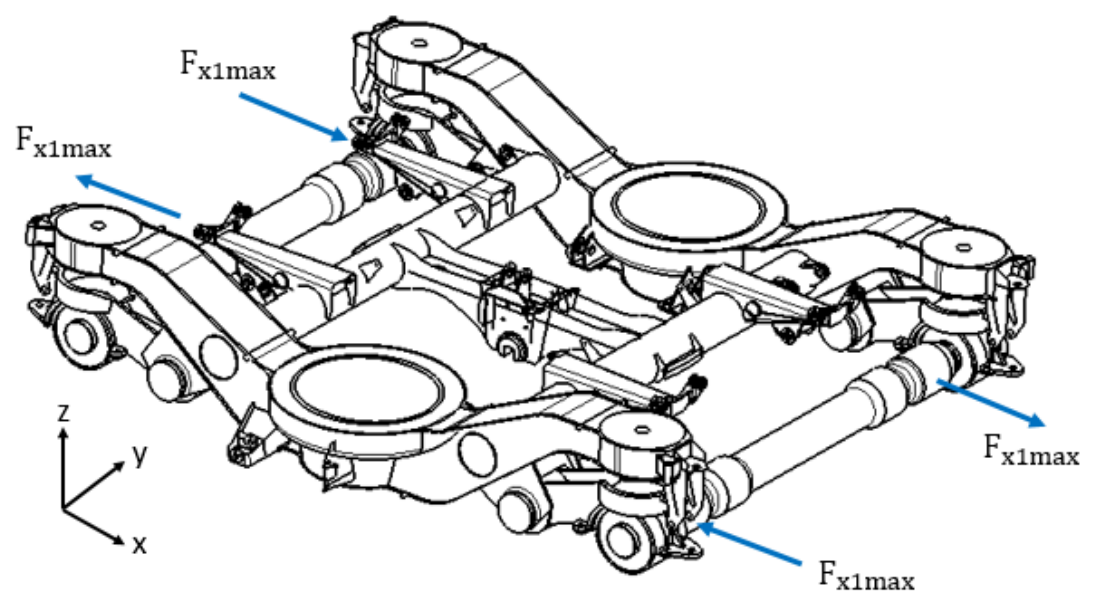

Şekil 8. Boyuna gelen kuvvetler

\subsubsection{Boyuna Gelen Makas Değiștirme Kuvvetleri}

Boyuna gelen makas değiştirme kuvvetleri hesaplanırken taşıyıcı boji üzerine $5 \mathrm{~g}^{\prime}$ lik bir ivme uygulanır. Motor bojilerin üzerine ise 3g'lik bir ivme uygulanır. Şekil 9'de gösterilen Y32 bojisi taşıyıcı boji olduğundan 5g değerindeki ivme uygulanmıştır [11].

$\mathrm{F}_{\mathrm{xs}}=5 \mathrm{~g} \mathrm{x} \mathrm{m}^{+}=282038 \mathrm{~N}$

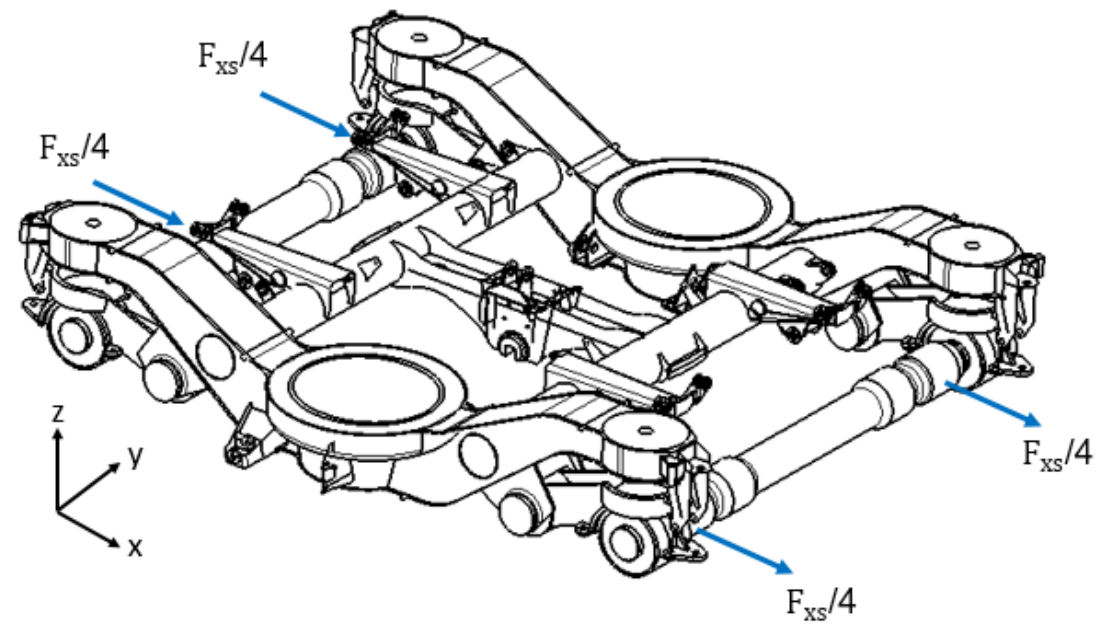

Şekil 9. Boyuna gelen makas değiş̧tirme kuvvetleri

\subsection{Burulma Durumları}

\subsection{1. \%1 Burulma Durumu}

Şekil 10'da gösterildiği üzere ilgili senaryo bojinin tekerleklerinden bir tanesinin diğer üçüne göre \%1 oranında yukarı yönde yükselmesi durumudur [11]. Bojinin iki aksı arasındaki mesafe $2560 \mathrm{~mm}$ 'dir. Bir adet tekerleğin yukarı yönde yükselme değeri: 


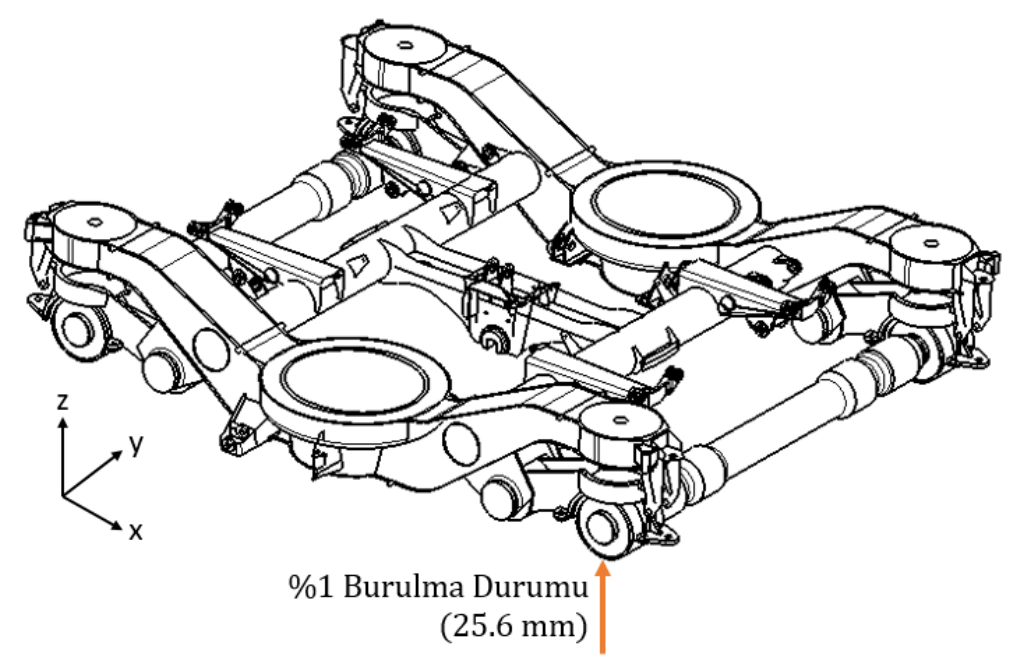

Şekil 10. \%1 Burulma durumu

\subsubsection{Tek Teker Boşta Durumu}

Aracın boş olduğu bir durumda (sadece düşey kuvvetlerin olduğu) bojinin bir tekerleğinin hiç yük taşımadığı durumdur. Şekil 11'da görüleceği üzere toplam yük üç teker tarafından taşınır [11].

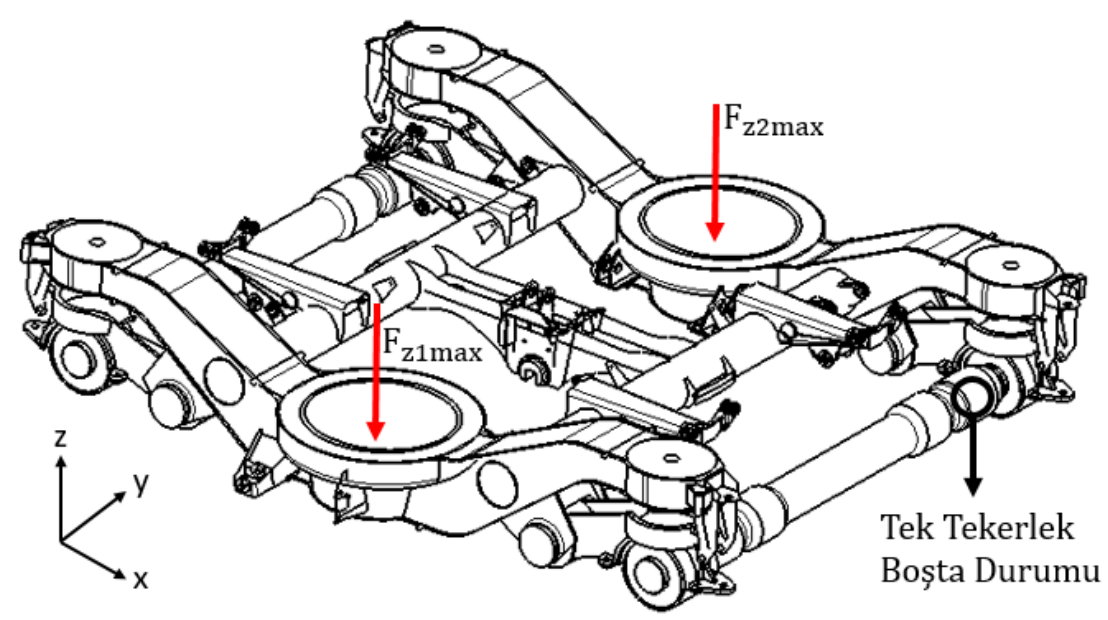

Şekil 11. Tek teker boşta durumu

\section{Araştırma Sonuçları ve Tartışma}

TS EN 13749:2011 standardına göre 4 adet aşırı yük durumu incelenmiştir [11]. Bu 4 durum aşağıda listelenmiştir:

Aşırı Yük Durumu 1 => Düşey Kuvvetler + Yanal Kuvvetler + \%1 Burulma Durumu

Aşırı Yük Durumu 2 => Düşey Kuvvetler + Boyuna Gelen Kuvvetler + \%1 Burulma Durumu

Aşırı Yük Durumu 3 => Düşey Kuvvetler + Boyuna Gelen Makas Değiştirme Kuvvetleri

Aşırı Yük Durumu 4 => Boş Aracın Düşey Kuvveti + Tek Teker Boşta Durumu

\subsection{Aşırı Yük Durumu 1}

\subsubsection{Sinır Şartları ve Kuvvetler}

Analizin çözümü için Şekil 12'de gösterilen sınır şartları ve kuvvetler uygulanmıştır. 
Aşırı Yük Durumu 1 => Düşey Kuvvetler + Yanal Kuvvetler + \%1 Burulma Durumu

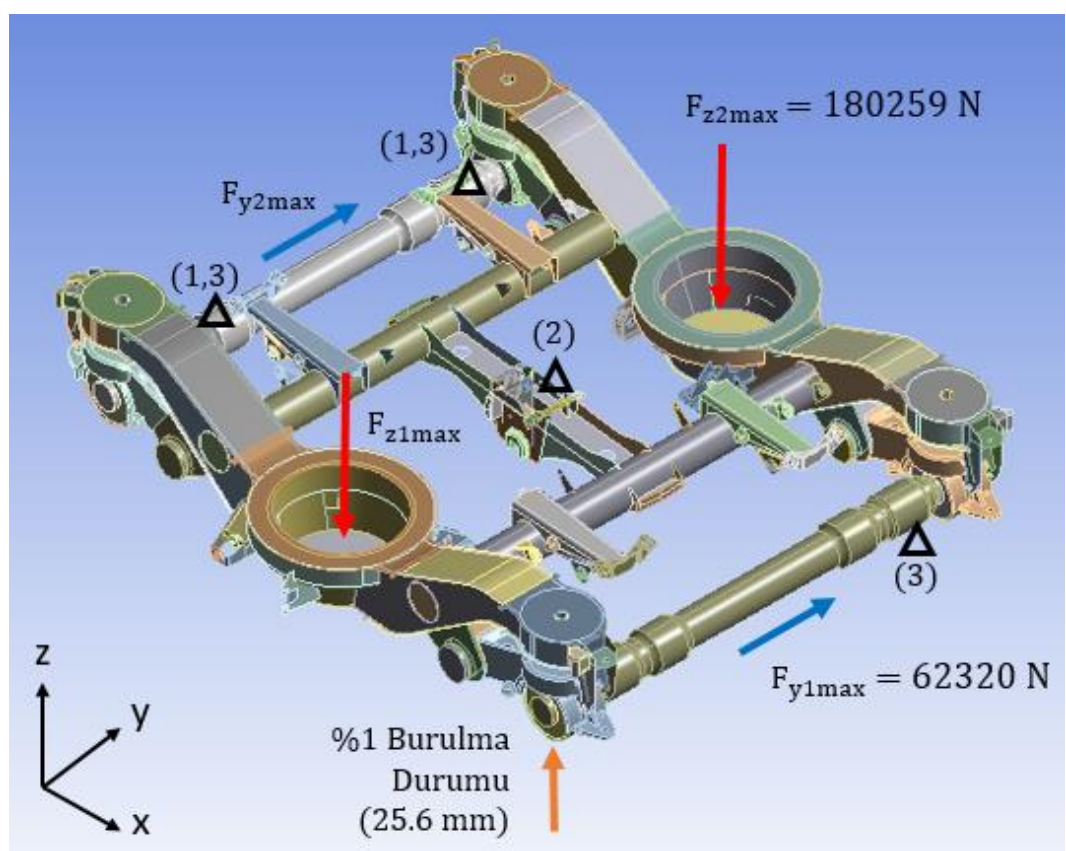

Şekil 12. Slnır şartları ve uygulanan kuvvetler (Aşırı Yük Durumu 1)

Analizlerde aşağıdaki koşullar uygulanır:

(1) X, akslardan bir tanesinin boylamsal yönde hareketi sabitlenir.

(2) Y, yanal stop plakasının yanal yönde hareketi sabitlenir.

(3) Z, aksların düşey yönde hareketi sabitlenir.

\subsection{2. Çözüm Ăğ Yakınsama Analizleri}

Y32 Bojisinin statik analizlerine geçilmeden önce çözüm ağı yakınsamas “Aşırı Yük Durumu 1" senaryosu için 4 farklı çözüm ağı kullanılarak gerçekleştirilmiştir. "Aşırı Yük Durumu 1" gerilme analizi toplamda 4 farklı çözüm ağ ile çözdürülmüş ve belirlenen yerlerdeki gerilme değerleri karşılaştırılmıştır. Şekil 13'de bojide çözüm ağı yakınsama analizleri için dikkate alınan noktalar görülmektedir.

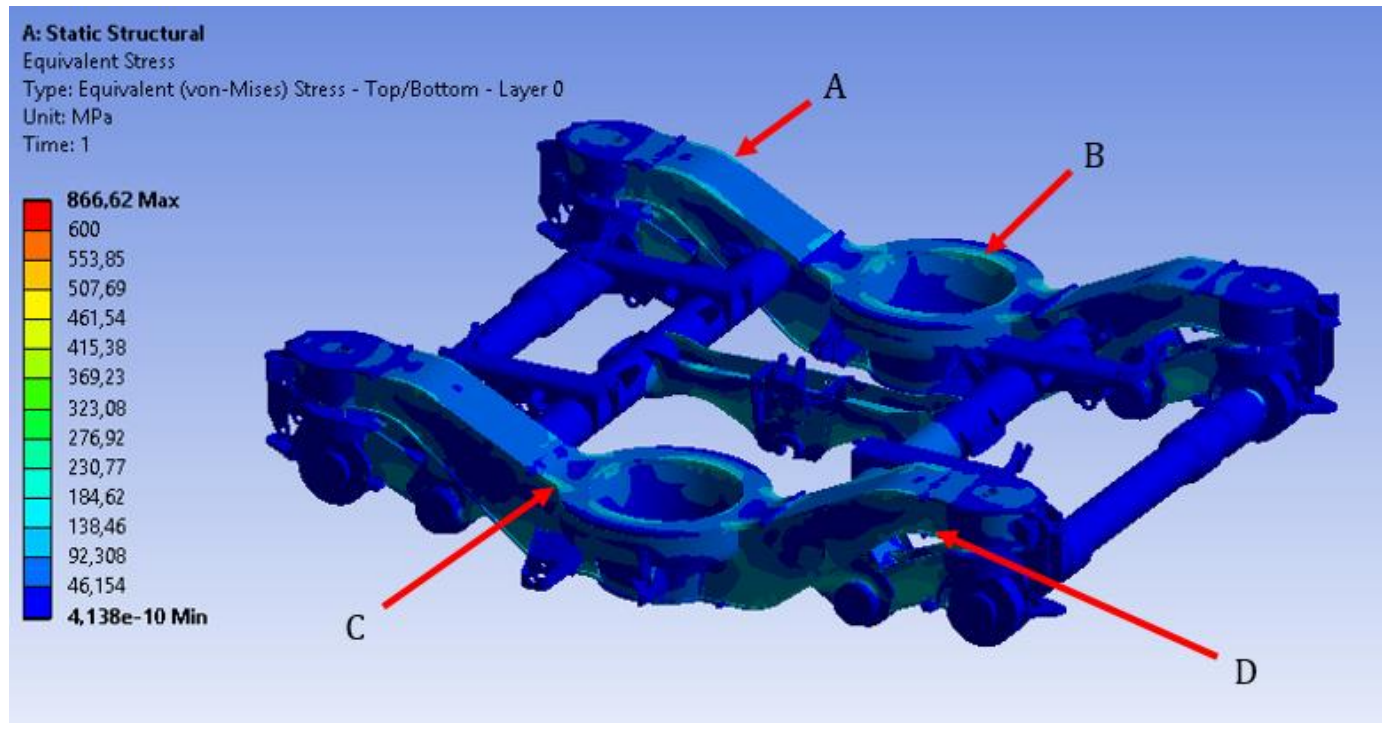

Şekil 13. Yakınsama için incelenen gerilme bölgeleri (Aşırı Yük Durumu 1) 


\section{Avrupa Bilim ve Teknoloji Dergisi}

4 Farklı çözüm ağındaki eleman ve düğüm noktaları (node) sayıları aşağıdaki tabloda verilmiştir.

Tablo 5. Çözüm ağlarındaki eleman sayıları ve düğüm noktaları sayıları

\begin{tabular}{|c|c|c|}
\hline & Eleman Say1s1 & Düğüm (Node) Say1s1 \\
\hline Çözüm Ağ1 1 & 346,494 & 541,997 \\
\hline Çözüm Ağ1 2 & 363,602 & 549,094 \\
\hline Çözüm Ağ1 3 & 449,596 & 624,785 \\
\hline Çözüm Ağ1 4 & 604,698 & 733,285 \\
\hline
\end{tabular}

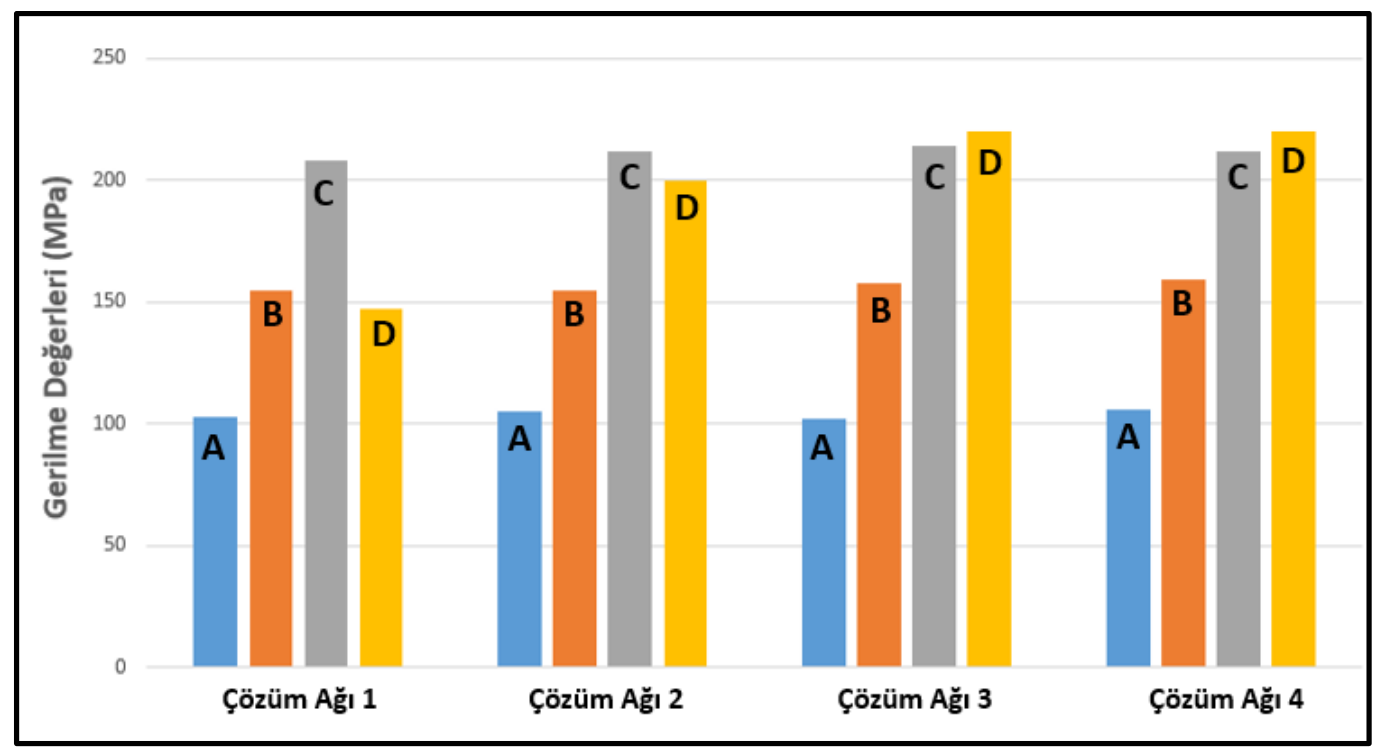

Şekil 14. Farklı çözüm ağlarındaki gerilme sonuçları (Aşırı Yük Durumu 1)

Şekil 14'de A, B, C ve D noktalarındaki gerilme değerlerinin 4 farklı çözüm ağındaki sonuçları gösterilmiştir. A, B ve C'deki gerilme değerleri 4 farklı çözüm ağına sahip analizlerde aynı hesaplanmıştır. D bölgesi ise Çözüm Ağı 3 ve Çözüm Ağı 4'te yakınsamıştır. "Çözüm Ağı 3" çalışmadaki tüm analizlerin yapılacağı model olarak seçilmiştir.

\subsubsection{Deformasyon Sonuçlart}

Aşırı yük durumu 1'de maksimum yerdeğiştirme 49.7 mm'dir ancak lokaldir. Şekil 15'de görüldüğü üzere bu değer yerine aks bağlantı bölgesinde oluşan $25.6 \mathrm{~mm}$ değeri dikkate alınmalıdır. 


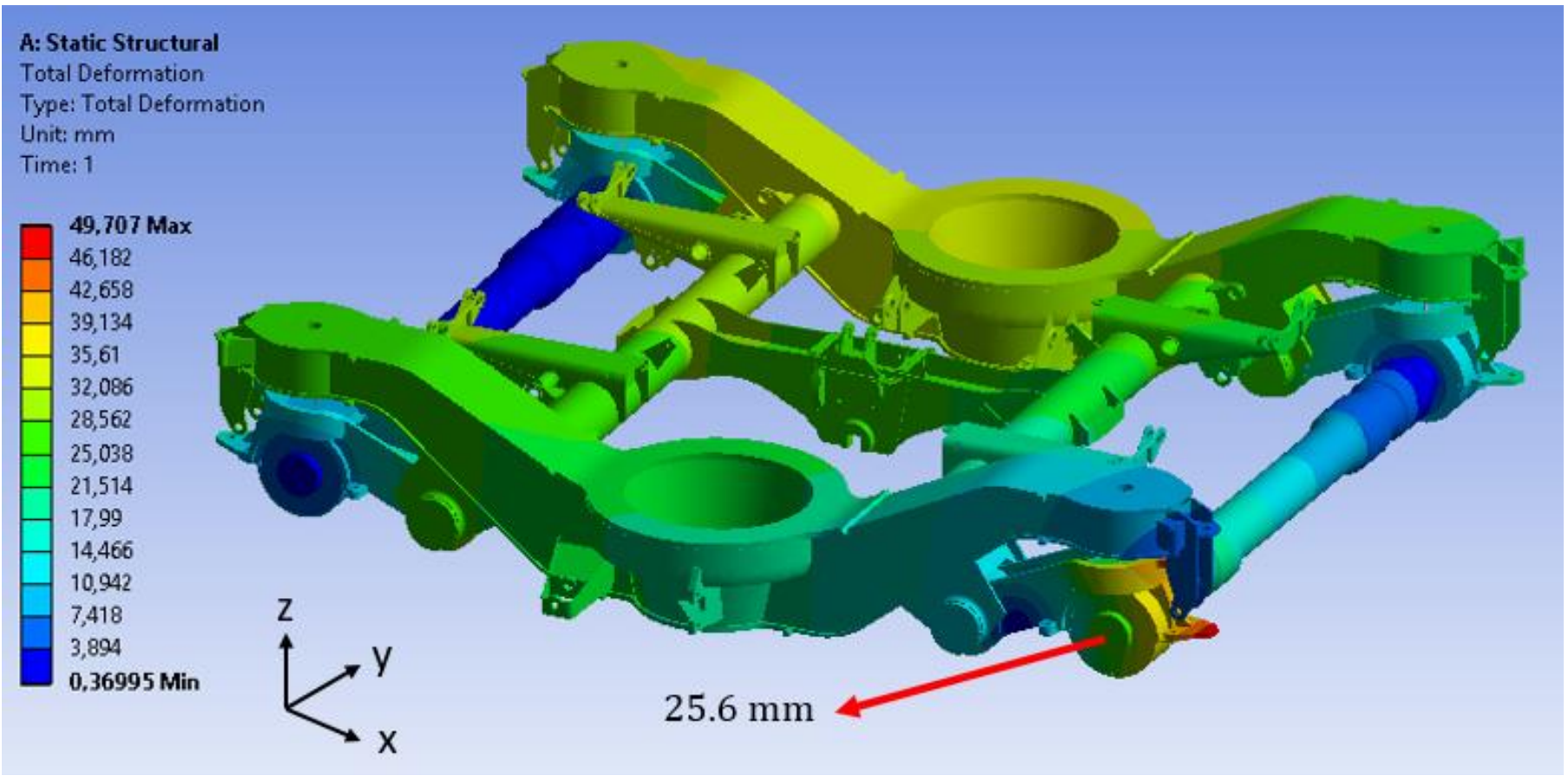

Şekil 15. Deformasyon sonuçları (Aşırı Yük Durumu 1)

\subsubsection{Gerilme Sonuçlart}

Analiz sonuçlarında eşdeğer gerilme (von-Mises) değerlerine bakılmıştır (Şekil 16).

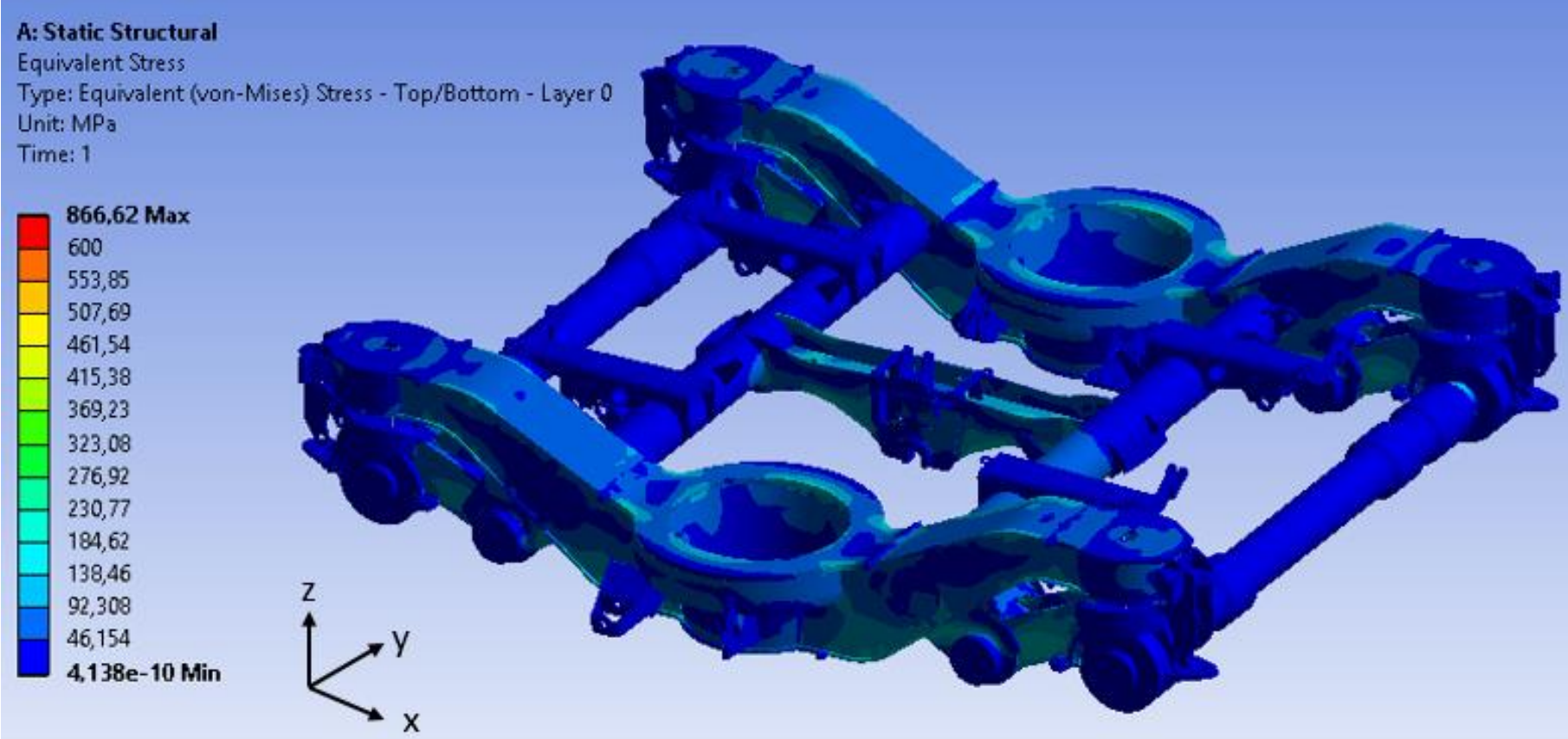

Şekil 16. Gerilme sonuçlarl genel görünüm (Aşırı Yük Durumu 1) 


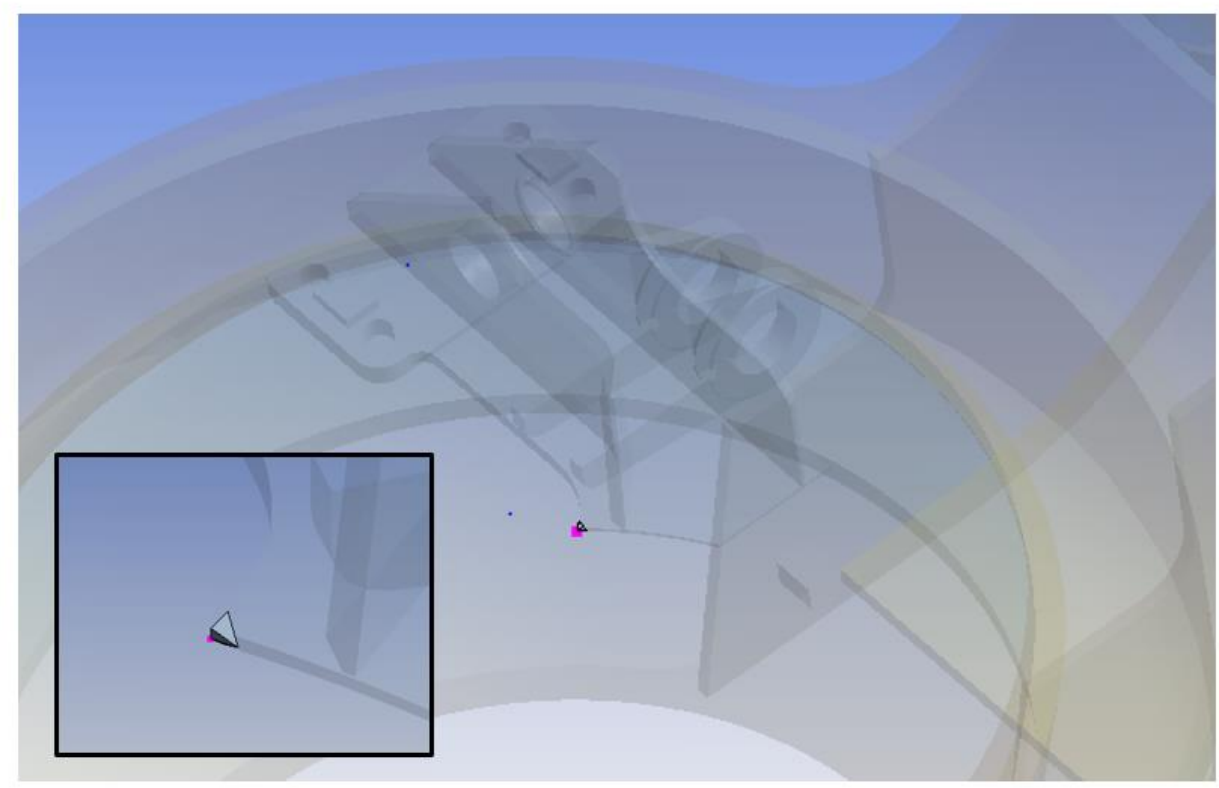

Şekil 17. Tekillik bölgesi genel ve detay görünüm (Aşırı Yük Durumu 1)

Sonlu elemanlar analizinde tekillik (Stress Singularity), gerilme değerinin teorik olarak sonsuza gittiği yerlerdir. Bunun en basit örneği bir noktaya uygulanacak tekil kuvvet olarak verilebilir. Kuvvetin uygulandığı alan sonsuz küçük olduğundan gerilme değeri de sonsuz çıkacaktır. Ayrıca çözüm ağında bulunan keskin köşeler veya boşluk civarı tekillik oluşturan bölgeler arasında sayılabilir. Tekillik bölgelerinde çözüm ağındaki eleman boyutlarının küçültülmesi gerilme değerini daha da büyütecektir. Şekil 17 'te Aşırı Yük Durumu 1 için gerilme skalasında verilen $866 \mathrm{MPa}$ değeri gösterilen keskin köş̧ede oluşmaktadır ve tekillik kaynaklıdır. Bu sebeple maksimum gerilme olarak bu değerin alınması gerçekçi olmayacaktır. Bunun yerine, Aşırı Yük Durumu 1'de maksimum eşdeğer gerilme (von Mises Stress) değeri sağ boylamsal yan kiriş üzerinde $220 \mathrm{MPa}$ olarak dikkate alınmıştır. Benzer şekilde çalışmanın devamında diğer yükleme senaryoları için de tekillik noktaları yerine gerilmenin maksimum çıktığı bölgeler detaylandırılarak verilmiştir.
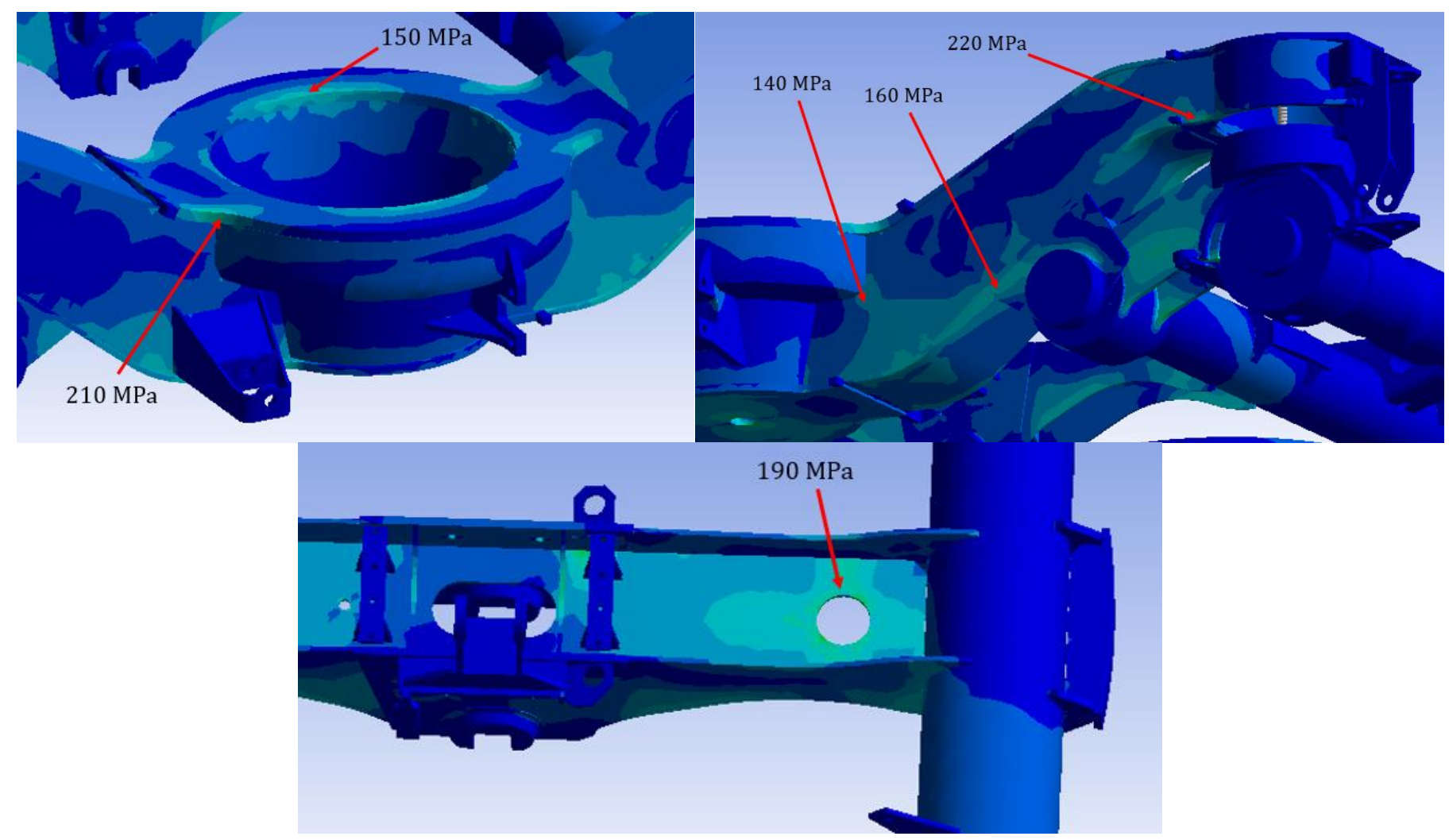

Şekil 18. Gerilme sonuçları detaylı görünüm (Aşırı Yük Durumu 1)

Aşırı Yük Durumu 1'de maksimum eşdeğer gerilme (von-Mises) değeri sağ boylamsal yan kiriş üzerinde 220 MPa'dır (Şekil 18). 


\subsection{Aşırı Yük Durumu 2}

\subsubsection{Sinur Şartları ve Kuvvetler}

Ansys Workbench programında aşağıda gösterilen sınır şartları ve kuvvetler uygulanmıştır (Şekil 19).

Aşırı Yük Durumu 2 => Düşey Kuvvetler + Boyuna Gelen Kuvvetler + \%1 Burulma Durumu

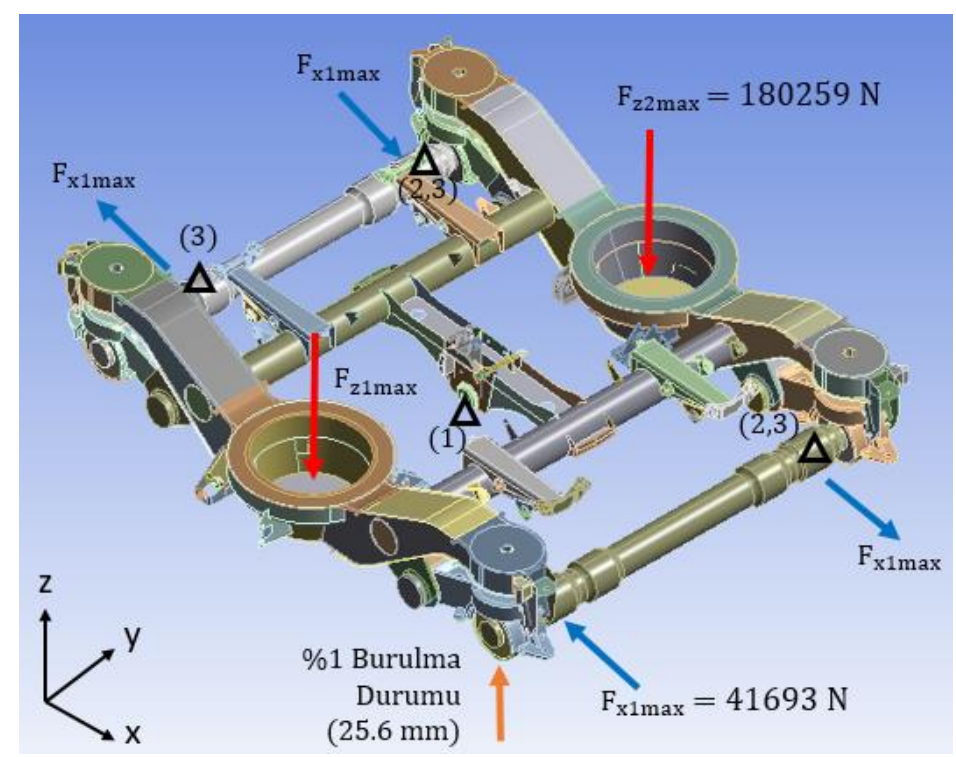

Şekil 19. Sinır şartları ve uygulanan kuvvetler (Aşırı Yük Durumu 2)

Analizlerde aşağıdaki koşullar uygulanır:

(1) X, boji çekme sisteminin boylamsal yönde hareketi sabitlenir.

(2) Y, aksların aynı taraftan yanal yönde hareketi sabitlenir.

(3) Z, aksların düşey yönde hareketi sabitlenir.

\subsubsection{Deformasyon Sonuçlart}

Aşırı yük durumu 2'de maksimum deformasyon sonucu 49.9 mm'dir ancak lokaldir. Bu değer yerine aks bağlantı bölgesinde oluşan 25,6 mm değeri dikkate alınmalıdır (Şekil 17).

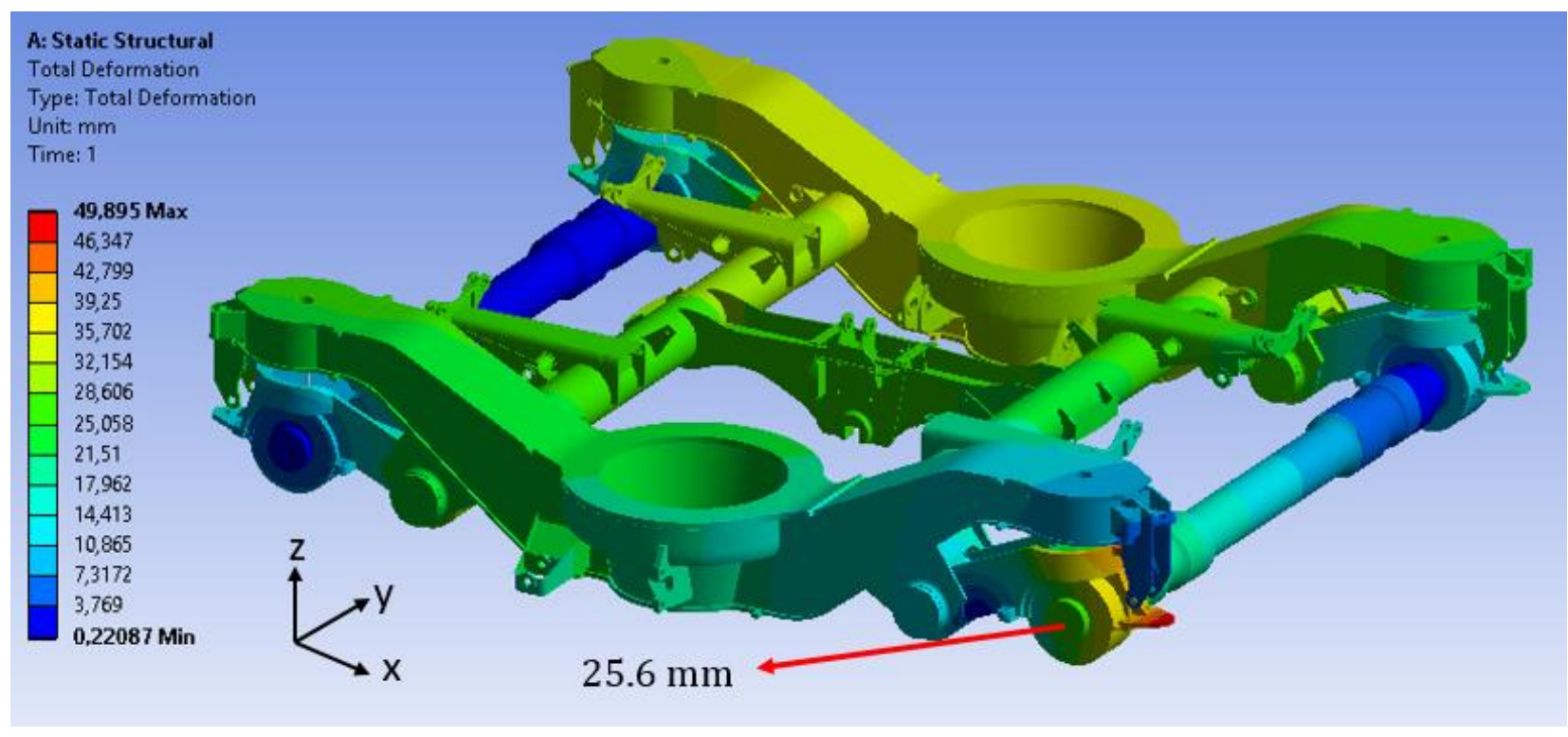

Şekil 20. Deformasyon sonuçları (Aşırı Yük Durumu 2) 


\subsubsection{Gerilme Sonuçları}

Analiz sonuçlarında eşdeğer gerilme (von-Mises) değerlerine bakılmıştır (Şekil 21).

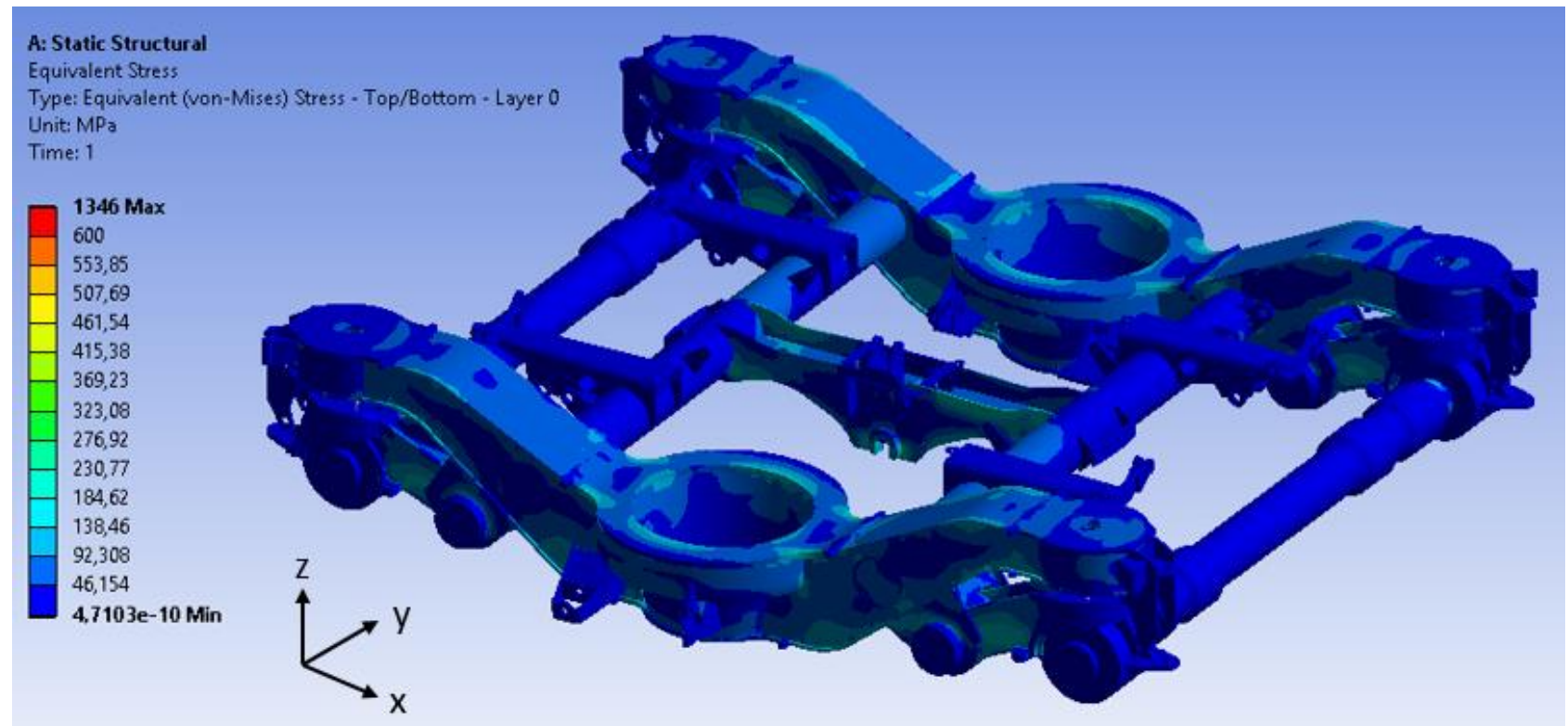

Şekil 21. Gerilme sonuçları genel görünüm (Aşırı Yük Durumu 2)
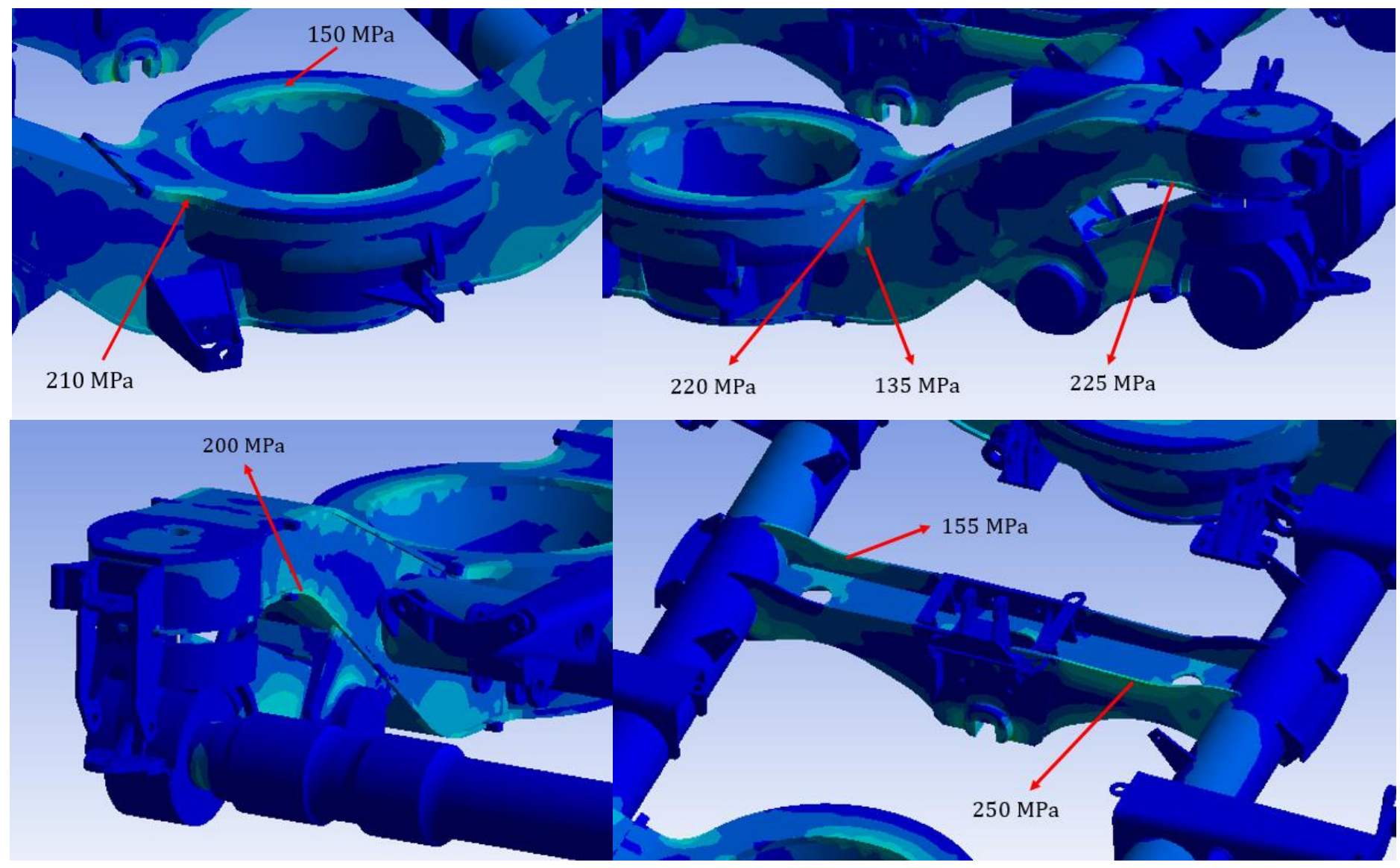

Şekil 22. Gerilme sonuçları detaylı görünüm (Aşırı Yük Durumu 2)

Aşırı yük durumu 2'de maksimum eşdeğer gerilme (von-Mises) değeri orta boylamsal kiriş üzerinde $250 \mathrm{MPa}$ 'dır (Şekil 22). 


\subsection{Aşırı Yük Durumu 3}

\subsubsection{Sinur Şartları ve Kuvvetler}

Ansys Workbench programında aşağıda gösterilen sınır şartları ve kuvvetler uygulanmıştır (Şekil 23).

Aşırı Yük Durumu 3 => Düşey Kuvvetler + Boyuna Gelen Makas Değiştirme Kuvvetleri

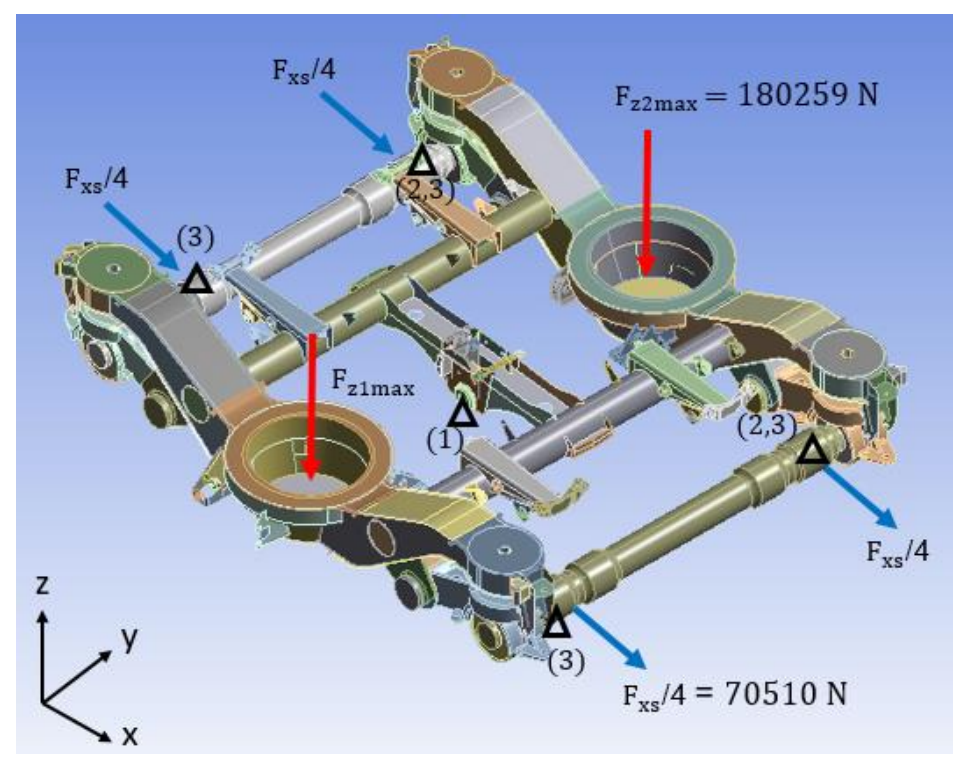

Şekil 23. Sinır şartları ve uygulanan kuvvetler (Aşırı Yük Durumu 3)

Analizlerde aşağıdaki koşullar uygulanır:

(1) X, boji çekme sisteminin boylamsal yönde hareketi sabitlenir.

(2) Y, aksların aynı taraftan yanal yönde hareketi sabitlenir.

(3) Z, aksların düşey yönde hareketi sabitlenir.

\subsubsection{Deformasyon Sonuçlart}

Aşırı yük durumu 3’te maksimum deformasyon sonucu 40,1 mm'dir (Şekil 24).

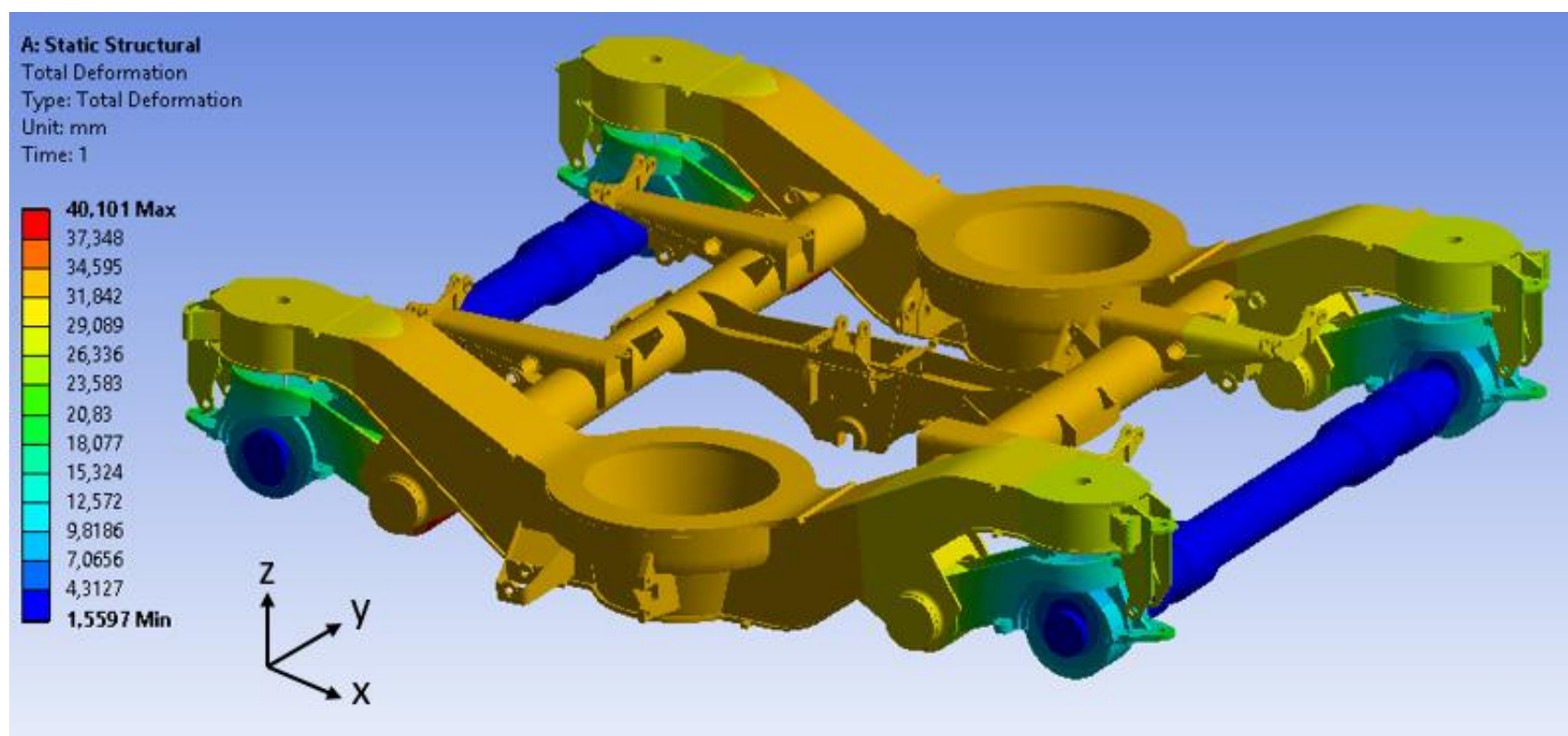

Şekil 24. Deformasyon sonuçları (Aşırı Yük Durumu 3) 


\subsubsection{Gerilme Sonuçları}

Analiz sonuçlarında eşdeğer gerilme (von-Mises) değerlerine bakılmıştır (Şekil 25).

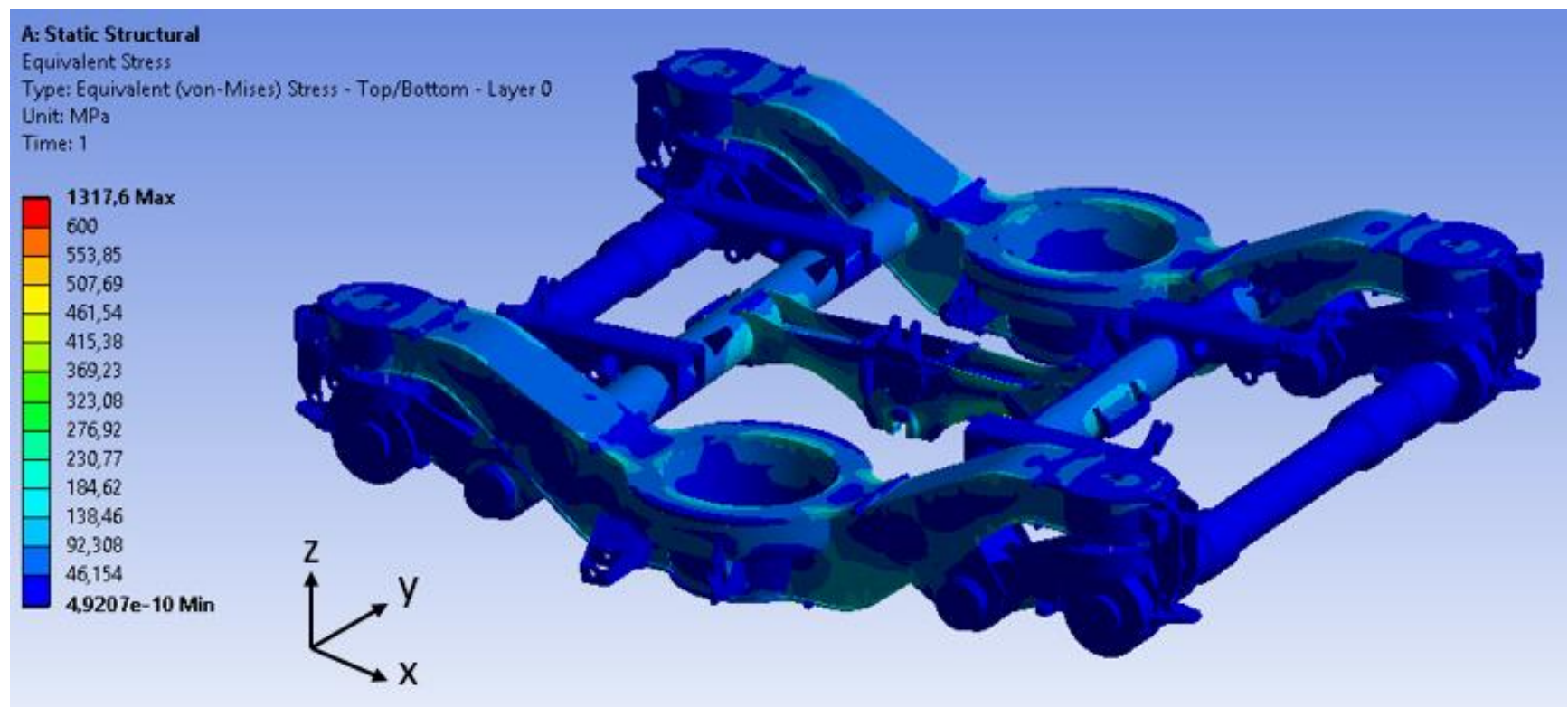

Şekil 25. Gerilme sonuçlarl genel görünüm (Aşırı Yük Durumu 3)

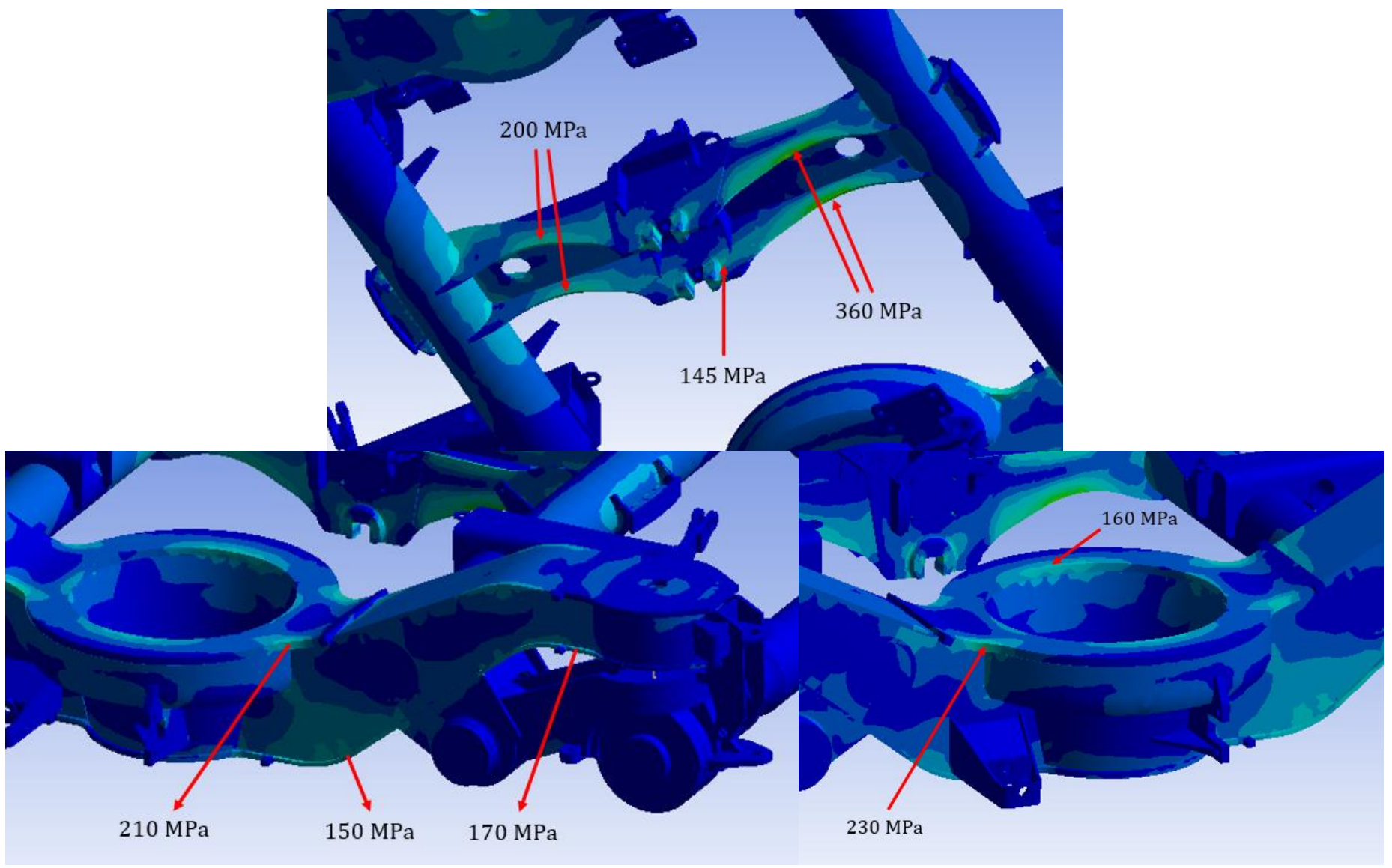

Şekil 26. Gerilme sonuçları detaylı görünüm (Aşırı Yük Durumu 3)

Aşırı yük durumu 3'te maksimum eşdeğer gerilme (von-Mises) değeri boylamsal orta kirişin alt bölgesinde 360 MPa'dır (Şekil 26). $\mathrm{Bu}$ değer malzemenin emniyetli gerilme değeri değeri olan $325 \mathrm{MPa}$ değerinin üzerinde olup, ilgili parça için iyileştirme yapılması gerekmektedir. 


\subsubsection{Tasarım Değiş̧ikliğ̈i Önerisi}

Şekil 27’te görüldüğü üzere boylamsal orta kirişteki gerilme değeri $360 \mathrm{MPa}$ 'dır. Bu değer kaynak yapılmış St52-3N plakasının akma değeri olan $325 \mathrm{MPa} n ı n$ üzerindedir. Bu neden ile 4 adet plakanın kalınlığ 6 mm'den 10 mm'ye çıkartılmıştır. Kalınlığ değiştirilen plakalar aşağıdaki şekilde gösterilmiştir.

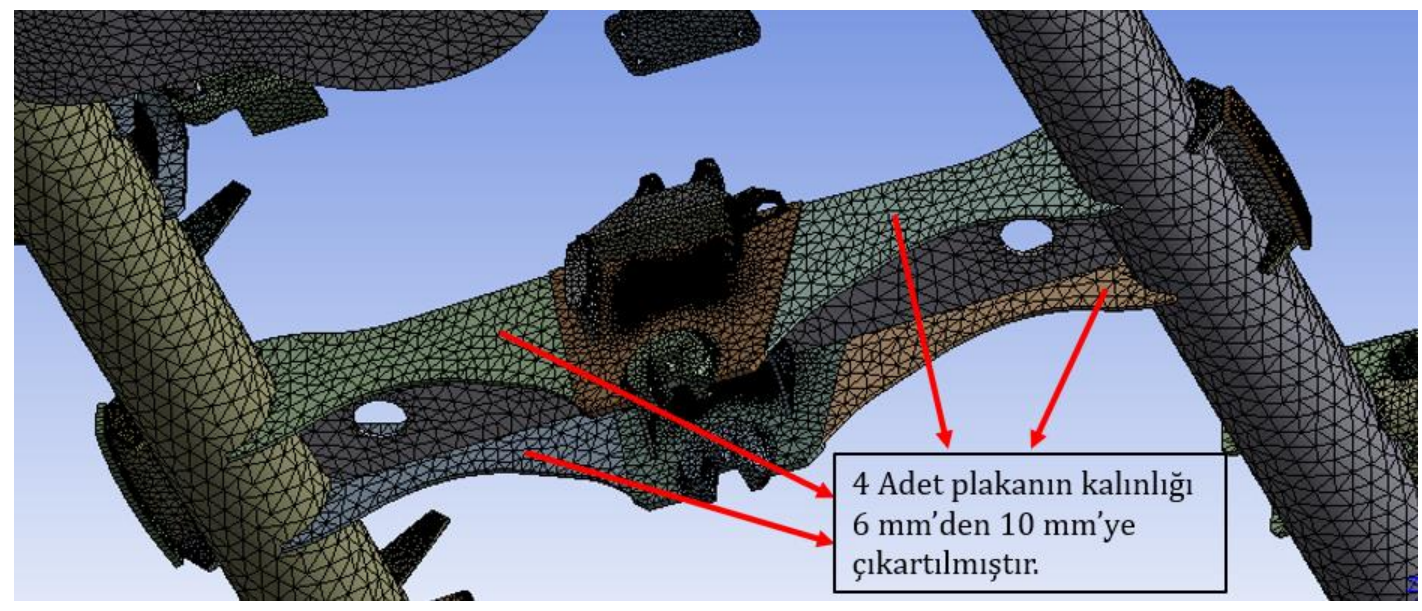

Şekil 27. Kalınlı̆̆ değiştirilen plakalar

Plaka kalınlıkları değiştirildikten sonra Aşırı Yük Durumu 3'ün analizi tekrarlanmıştır ve ilgili plakalardaki gerilme değerleri aşağıda verilmiştir.

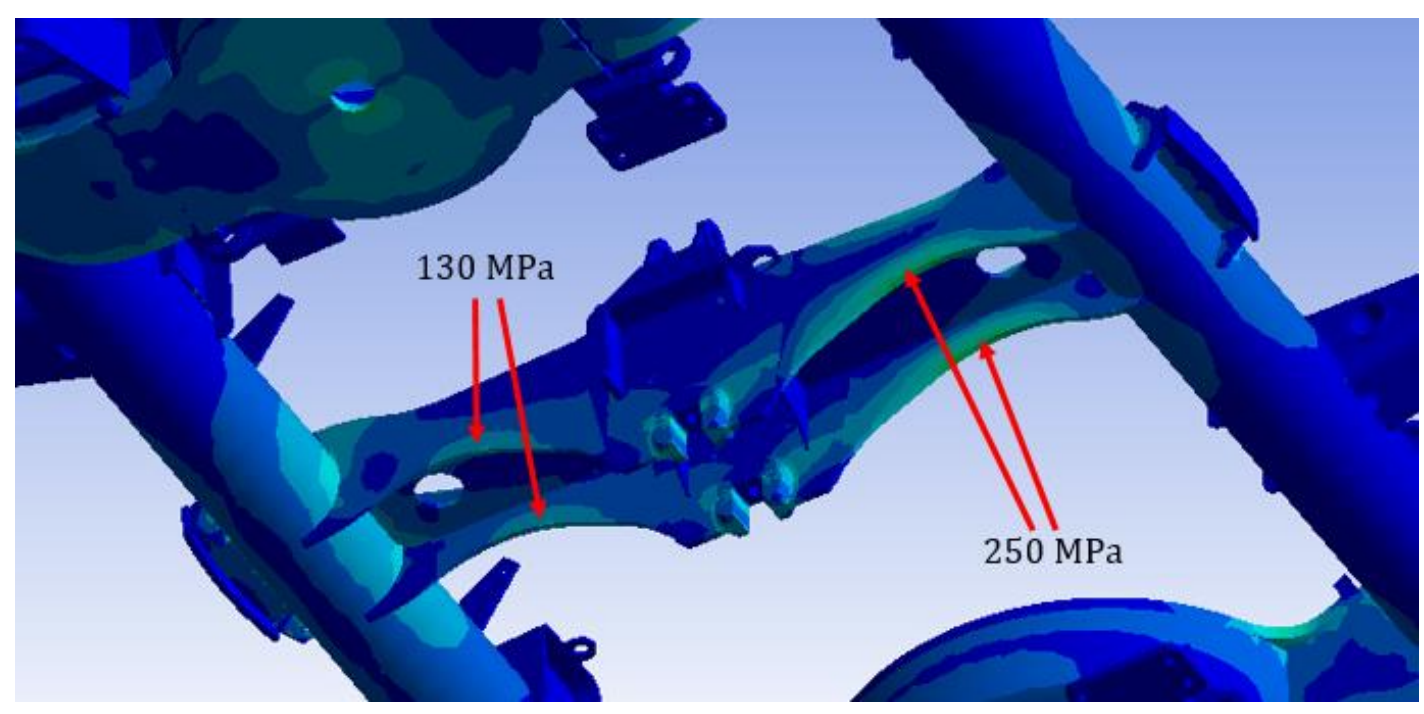

Şekil 28. Tasarım önerisinden sonraki gerilme değerleri

Şekil 28 ’te verilen görselden tasarım değişikliği öncesinde $360 \mathrm{MPa}$ olan gerilme değeri tasarım değişikliğinden sonra $250 \mathrm{MPa}$ değerine düştüğü anlaşılmaktadır.

\subsection{Aşırı Yük Durumu 4}

\subsubsection{Sinır Şartları ve Kuvvetler}

Ansys Workbench programında aşağıda gösterilen sınır şartları ve kuvvetler uygulanmıştır (Şekil 29).

Aşırı Yük Durumu 4 => Boş Aracın Düşey Kuvveti + Tek Tekerlek Boşta Durumu 


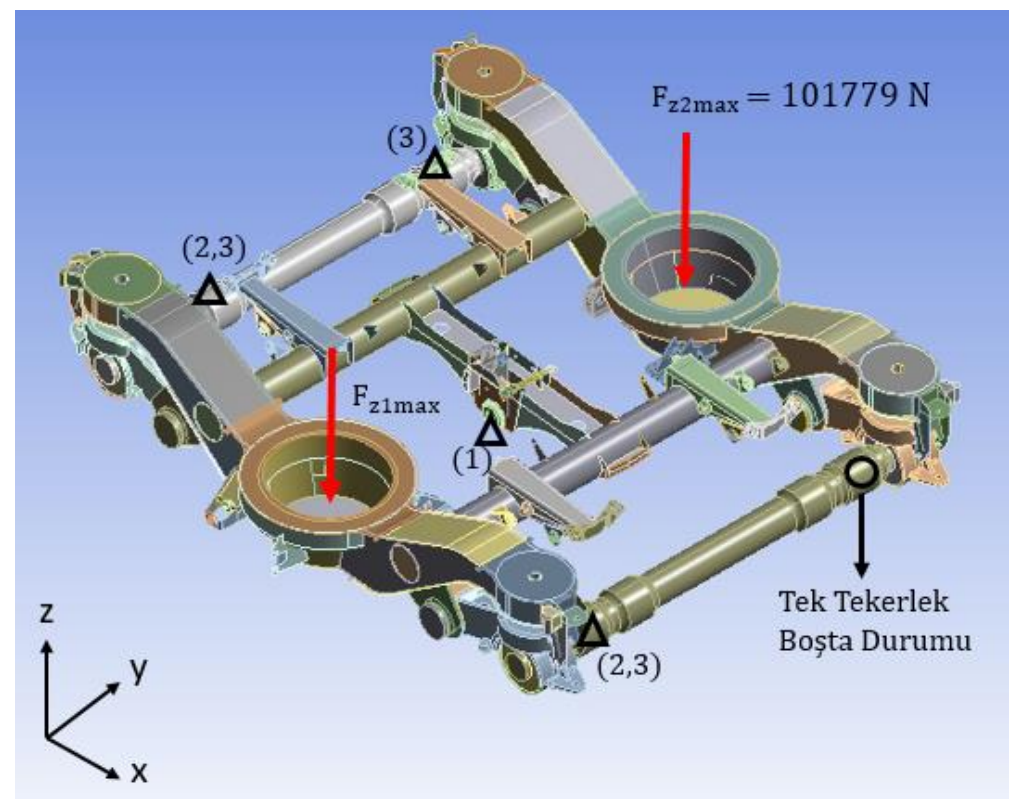

Şekil 29. Sinır şartları ve uygulanan kuvvetler (Aşırı Yük Durumu 4)

Analizlerde aşağıdaki koşullar uygulanır:

(1) X, boji çekme sisteminin boylamsal yönde hareketi sabitlenir.

(2) Y, aksların aynı taraftan yanal yönde hareketi sabitlenir.

(3) Z, aksların düşey yönde hareketi sabitlenir.

\subsubsection{Deformasyon Sonuçları}

Aşırı yük durumu 4'te maksimum deformasyon sonucu 27.8 mm'dir (Şekil 30).

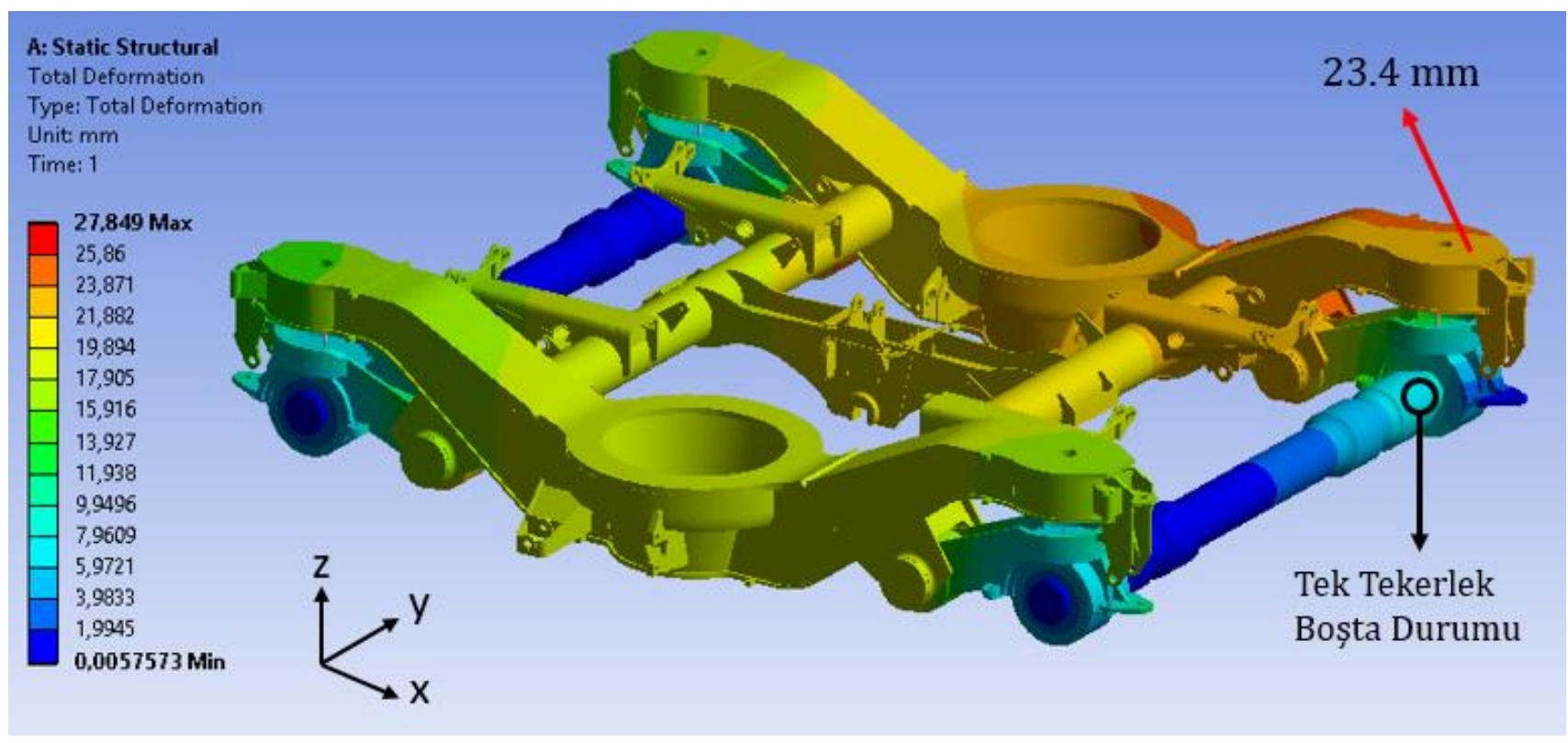

Şekil 30. Deformasyon sonuçları (Aşırı Yük Durumu 4) 


\subsubsection{Gerilme Sonuçları}

Analiz sonuçlarında eşdeğer gerilme (von-Mises) değerlerine bakılmıştır (Şekil 31).

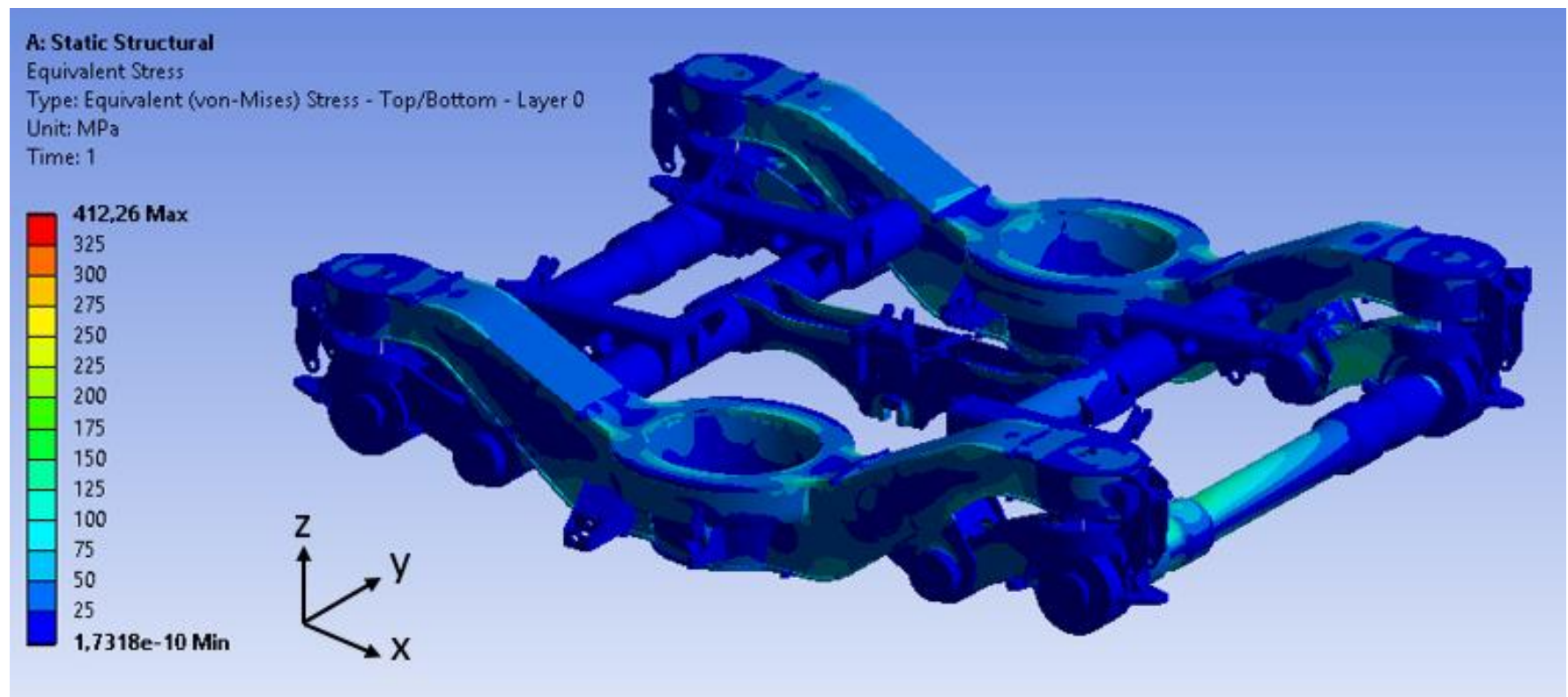

Şekil 31. Gerilme sonuçları genel görünüm (Aşırı Yük Durumu 4)

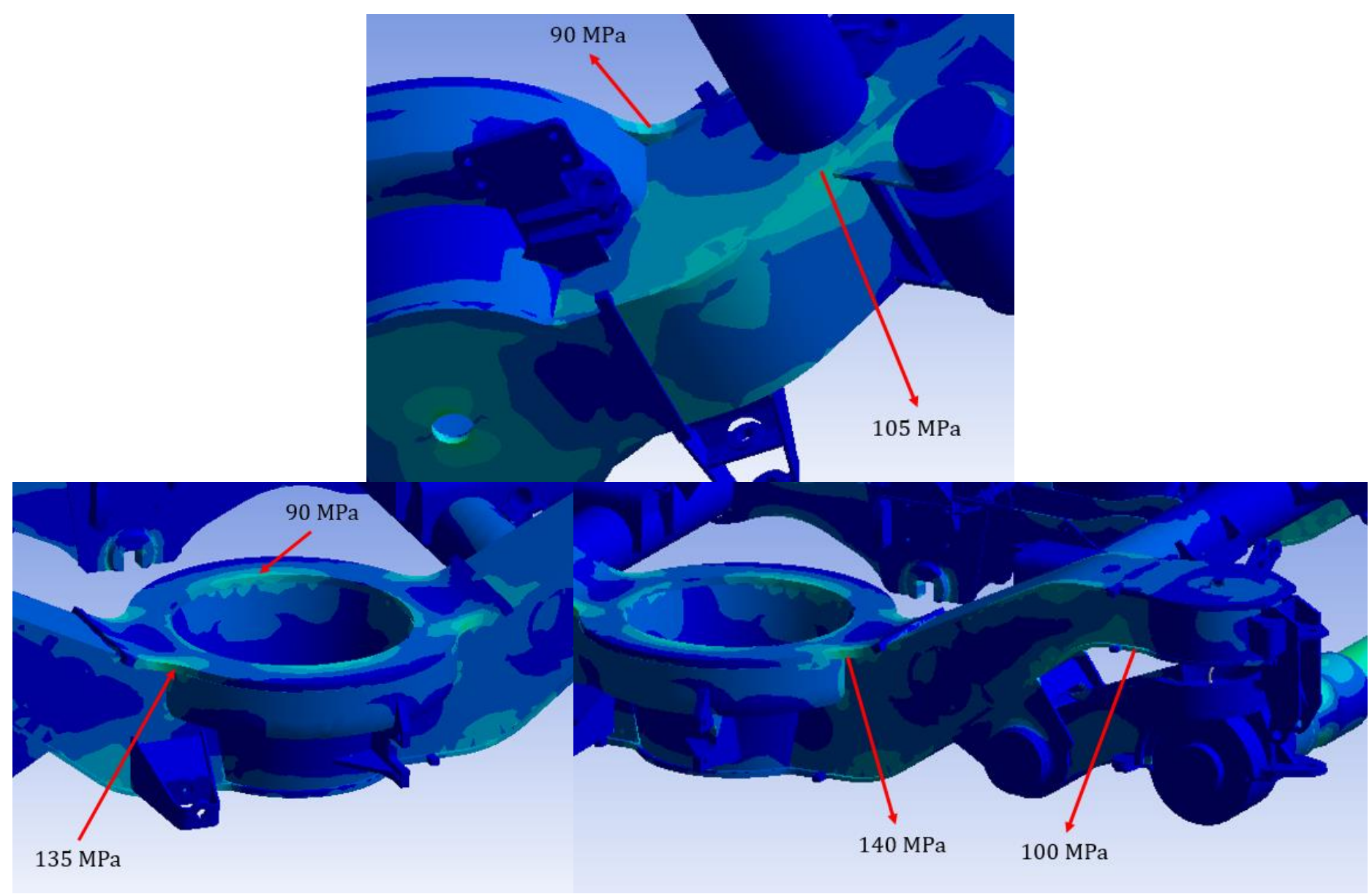

Şekil 32. Gerilme sonuçları detaylı görünüm (Aşırı Yük Durumu 4)

Aşırı yük durumu 4'te maksimum eşdeğer gerilme (von-Mises) değeri sağ boylamsal kirişte 140 MPa'dır (Şekil 32). 


\subsection{Tartışma}

Sünek malzemelerde sonlu elemanlar analizi yaparken eşdeğer gerilme (von-Mises) değeri kullanılır. Gevrek malzemelerde ise asal gerilme değerlerini kullanmak daha uygundur. Y32 bojisinin plakalarında kullanılan çeliğin kalitesi St52-3N'dir. Bu nedenle statik analizlerde eşdeğer gerilme değeri kullanılmıştır. Bojinin statik analiz sonuçlarının TS EN 13749:2011 standardına göre kabul görmesi için malzemenin plastik deformasyona uğramaması gerekmektedir [11].

Gerilme sonuçlarının genel görünüm şekillerine bakıldığında, gerilme skalalarının akma gerilmesinin üzerinde olduğu görülmektedir. Bunun nedeni, çözüm ağı uygulanan modelde tekillik bölgelerinin bulunmasıdır. Bu neden ile gerilme değerleri, tekilliğe neden olan bölgelerin biraz daha uzağından alınmıştır. Böylelikle daha doğru gerilme sonuçlarına ulaşılmıştır.

Aşıırı Yük Durumu 3'te boylamsal orta kirişin maruz kaldığı gerilme değeri 360 MPa olarak çıkmıştır. St52-3N malzemesinden yapılmış ve birbirine kaynak ile montajlanmış plakaların akma gerilmesi $325 \mathrm{MPa}$ 'dır. Bu nedenle ilgili bölgedeki plakaların kalınlığı 6 mm'den 10 mm'ye çıkartılmıştır. Bu yeni tasarım ile analiz tekrarlandığında gerilme değeri $250 \mathrm{MPa}$ olarak elde edilmiştir. Diğer aşırı yük durumu analizlerinde herhangi bir gerilme değeri akma gerilmesinin üzerinde çıkmamıştır. 


\section{Sonuç}

Raylı taşıtlarda kullanılan en kritik elemanlardan birisi olan boji şasisinin son derece güvenli tasarlanması ve imal edilmesi önemli bir gerekliliktir. Bunun için raylı sistemlerde güvenlik açısından katı kuralları içeren standartlar kullanılmaktadır. TS EN 13749 standardı Türkiye tarafından kabul edilen ve uygulanan bir standarttır. . Bu standart boji şasilerinin yapısal gerekliliklerini belirler.

Çalışmanın birinci bölümünde, Y32 bojisinin şasi ve ekipmanlarına dair statik analizler TS EN13749 standardı çerçevesinde gerçekleştirilmiştir. Gerçekleştirilen analizleri doğrudan ilgilendirdiği için sonlu elemanlar yöntemi ve eşdeğer gerilme hakkında bilgiler verilmiştir. Ardından analiz edilen malzemelerin mekanik özellikleri anlatılmıştır. Y32 boji geometrisi analiz için 3 boyutlu olarak hazırlanmış ve ardından statik analizler gerçekleştirilmiştir.

Y32 Bojisinin statik analizlerinde 4 adet aşırı yük durumu incelenmiştir. En yüksek gerilme değeri Aşırı Yük Durumu 3 'te meydana gelmektedir. Aşırı Yük Durumu 3'te boylamsal orta kirişteki gerilme değeri $360 \mathrm{MPa}$ olarak elde edilmiştir. Bu değer kaynak yapılmış St52-3N plakasının akma değeri olan 325 MPa'nın üzerindedir. Bu nedenle, 4 adet plakanın kalınlığı 6 mm'den 10 mm'ye çıkartılmıştır. Analizde bulunan gerilme değeri ilgili plakalarda plastik deformasyona neden olacağ için boji tasarımının revize edilmesi önerilmiştir.. Önerilen yeni tasarım için analiz tekrarlandığında gerilme değeri $250 \mathrm{MPa}$ olarak elde edilmiştir. Böylece, aşırı yük senaryoları altında gerçekleştirilen statik analizler çerçevesinde Y32 boji şasisi TS EN 13749 standardının gerekliliklerini karşılamaktadır.

\section{Kaynakça}

[1] S. Sabırlı, "Bir Raylı Taşıt Bogisinin Sonlu Elemanlar Yöntemiyle Yorulma Analizi” Yüksek lisans tezi, Makine Mühendisliği Anabilim Dalı, İstanbul Teknik Üniversitesi, İstanbul, 2012.

[2] Y. Zhang, P. Wu, Y. Song, "Strength Test and Modal Analysis for a Standardized High-Speed EMU Motor Bogie Frame", ICSMIM2015 Conference, 1128-1132.

[3] C. Bhadraiah, "Stress Analysis of Bogie Frame Structure”, Yükek lisans tezi, Makine Mühendisliği Anabilim Dalı, Blekinge Institute of Technology, Karlskrona, İsveç, 2017.

[4] S. Haldar, R. Verma, "Analysis of Bogie Frame Manufactured with Different Processes", International Journal of Mechanical Engineering, 4 (5):22-26, 2017.

[5] W. Tang, "Fatigue Strength and Modal Analysis of Bogie Frame for DMUs Exported to Tunisia", Journal of Applied Mathematics and Physics, 342-348, 2014.

[6] J. Dizo, J. Harusinec, M. Blatnicky, "Structural Analysis of a Modified Freight Wagon Bogie Frame", MATEC Web of Conferences 134, 00010, 2017.

[7] A. Cera, "Analysis of methodologies for fatigue calculation for railway bogie frames", Trenitalia S.P.A., Floransa, İtalya.

[8] J. Dai, "The Design of Bullet Train Process Bogie and the Finite Element Analysis of Frame Strength", International Conference on Material Science and Application, 926-931, 2015.

[9] J. Kim, N. Kim, “Structural Assessment for Bogie Frame of 180 km/h Korean Tilting Train”, Key Engineering Materials, 297(300): 345-350, 2005.

[10] H. Huang, L. Chen, "Strength Simulation of a Railway Bogie Frame based on EN 13749”, Journal of Technology, 33(4): 209214, 2018.

[11]European Committee for Standardization, "EN 13749 : 2011 Railway Applications - Wheelsets and Bogies - Method of Specifying the Structural Requirements of Bogie Frames.” Bürüksel, Belçika, 2011.

[12] Trains of Turkey, "TVS 2000 Cars", http://www.trainsofturkey.com/index.php/Cars/TVS2000 (15.01.2019 tarihinde alınmıştır.)

[13] Material Properties Database, "S355J2G3”, https://www.makeitfrom.com/material-properties/EN-1.0570-S355J2G3-NonAlloy-Steel (10.02.2019 tarhinde alınmıştır.)

[14] Material Properties Database, “GE240”, https:/www.makeitfrom.com/material-properties/EN-1.0446-GE240-Cast-Non-AlloySteel (10.02.2019 tarhinde alınmıştır.)

[15] European Committee for Standardization, "Railway applications - Wheelsets and bogies - Axles - Product requirements." Bürüksel, Belçika, 2010.

[16]“Element Quality”, http://research.me.udel.edu/ lwang/teaching/MEx81/ansys56manual.pdf (17.02.2019 tarihinde alınmıştır.)

[17] European Committee for Standardization. "EN 15663 : 2017 Railway applications - Definition of Vehicle Referance Masses" Bürüksel, Belçika, 2017. 